\title{
Effectiveness of contrast-associated acute kidney injury prevention methods; a systematic review and network meta- analysis
}

Khalid Ahmed ${ }^{1,2^{*}}$ (D), Terri McVeigh ${ }^{1}$, Raminta Cerneviciute', Sara Mohamed ${ }^{1}$, Mohammad Tubassam², Mohammad Karim ${ }^{3}$ and Stewart Walsh ${ }^{1,2,4}$

\begin{abstract}
Background: Different methods to prevent contrast-associated acute kidney injury (CA-AKI) have been proposed in recent years. We performed a mixed treatment comparison to evaluate and rank suggested interventions.

Methods: A comprehensive Systematic review and a Bayesian network meta-analysis of randomised controlled trials was completed. Results were tabulated and graphically represented using a network diagram; forest plots and league tables were shown to rank treatments by the surface under the cumulative ranking curve (SUCRA). A stacked bar chart rankogram was generated. We performed main analysis with 200 RCTs and three analyses according to contrast media and high or normal baseline renal profile that includes 173, 112 \& 60 RCTs respectively.

Results: We have included 200 trials with 42,273 patients and 44 interventions. The primary outcome was $\mathrm{Cl}$-AKl, defined as $\geq 25 \%$ relative increase or $\geq 0.5 \mathrm{mg} / \mathrm{dl}$ increase from baseline creatinine one to 5 days post contrast exposure. The top ranked interventions through different analyses were Allopurinol, Prostaglandin E1 (PGE1) \& Oxygen (0.9647, $0.7809 \& 0.7527$ in the main analysis). Comparatively, reference treatment intravenous hydration was ranked lower but better than Placebo (0.3124 VS 0.2694 in the main analysis).
\end{abstract}

Conclusion: Multiple CA-AKI preventive interventions have been tested in RCTs. This network evaluates data for all the explored options. The results suggest that some options (particularly allopurinol, PGE1 \& Oxygen) deserve further evaluation in a larger well-designed RCTs.

Keywords: Contrast induced acute kidney injury, Contrast nephropathy, Prevention methods, Contrast associated acute kidney injury

\section{Background}

\section{Rationale}

Contrast Associated acute kidney injury (CA-AKI) also known as Contrast-induced acute kidney injury (CI-AKI) previously known as contrast induced nephropathy (CIN) is the third leading cause of hospital-acquired acute renal injury, accounting for $12 \%$ of cases [1]. It is defined as an abrupt deterioration in renal function

\footnotetext{
* Correspondence: Khalidmd20@gmail.com

'Lambe Institute for Translational Research, Discipline of Surgery National

University of Ireland, Galway, Republic of Ireland

2Department of Vascular surgery, Galway University Hospital, Galway,

Republic of Ireland

Full list of author information is available at the end of the article
}

following exposure to contrast media $(\mathrm{CM})$ in the absence of other aetiological factors [2]. The absolute and relative values used to define CI-AKI vary, but are most commonly quoted as a relative increase of $>25 \%$ or an absolute increase of $0.5 \mathrm{mg} / \mathrm{dL}$ and $\geq 0.3 \mathrm{mg}$ from baseline serum creatinine measurement within 1-3 (4-5 days less frequently used) of contrast exposure [3-7]. In CI-AKI, the serum creatinine level begins to rise within $24 \mathrm{~h}$ of contrast exposure, peaking after $72 \mathrm{~h}$, and usually returning to baseline within 1-3 weeks [6].

The proposed pathophysiology of CI-AKI is acute tubular necrosis. The underlying mechanisms are thought to be vasoconstriction, leading to cellular hypoxia, or direct

(c) The Author(s). 2018 Open Access This article is distributed under the terms of the Creative Commons Attribution 4.0 International License (http://creativecommons.org/licenses/by/4.0/), which permits unrestricted use, distribution, and 
toxicity of contrast media to renal tubular cells $[8,9]$. Multiple therapies have been postulated to prevent CI-AKI act by affecting these mechanisms or their metabolic mediators.

There is ongoing discussion about the impact of new contrast media on the size of the problem and the outcomes of prevention methods or even the existence of the problem, on the other side these conclusions were challenged as coming only from retrospective studies that does not take in account patients factors or indications for using contrast media in deferent cases with deferent baseline renal profile $[10,11]$.

In recent years, there have been many systematic reviews and meta-analyses for direct pair-wise comparisons of individual interventions suggested for CI-AKI prevention. With so many options explored, it is difficult to determine the treatment options most likely to show benefit in large-scale trials. Unlike conventional meta-analysis, Network facilitates simultaneous comparison of indirect relationships between multiple interventions. The network can establish an estimate of comparative efficacy between two or more treatments compared to the same control intervention [12-14]. We undertook a network-meta-analysis of preventive strategies for CA-AKI to determine the treatment most likely to be beneficial based upon currently available evidence.

\section{Methods}

We conducted a systematic review and network meta-analysis in accordance with the PRISMA extension for Network Meta-Analyses [15].

\section{Protocol and registration}

No registered protocol.

\section{Eligibility criteria}

We consider all randomized controlled trials in which patients underwent a contrast-enhanced procedure with CI-AKI as a primary or secondary outcome. We evaluate studies in which a prevention method was compared to placebo, control or other intervention. Excluded from the analysis were other research designs, including non-randomised control trials; clinical trials; trials comparing different doses of the same intervention and trials using re-randomization of the same sample (Crossover design). For this review, we defined CI-AKI as an increase of more than or equal to $0.5 \mathrm{mg} / \mathrm{dl}$ and/or $25 \%$ increase in baseline serum Creatinine one to 5 days post contrast exposure [3].

\section{Information sources}

We searched for English-language trials in PubMed, Embase and Cochrane Central Register of Controlled
Trials without any date restrictions. The final search was undertaken on 25th April 2017.

\section{Search strategy and study selection}

Two authors (Ahmed, Walsh) searched Electronic databases using Mesh terms "contrast nephropathy", "contrast nephropathy prophylaxis", "contrast nephropathy prevention", with the Boolean operator "OR" as appropriate. Titles and abstracts of identified studies were assessed first, with full texts reviewed thereafter. The study was included if the methodology fulfilled inclusion criterion.

\section{Data collection}

Data were recorded concerning sample size, adverse events, procedures performed, study inclusion and exclusion criteria, intervention type and dose, contrast media volume, CI-AKI definition, and contrast medium type and osmolality.

\section{The geometry of the network}

A network diagram was created using NetMetaXL tool to graphically represent the size of the trial and the number of pairwise comparisons between interventions. The size of each intervention node is proportional to a number of patients included in the trial, while the thickness of interconnecting lines is proportional to the number of pairwise comparisons between any two interventions.

\section{Risk of bias}

The Cochrane tool for risk of bias assessment (RevMan 5.3) was used to assess bias within individual studies. A bias graph was generated to portray the risk of bias overall across the included trials.

\section{Summary measures}

Odds ratios with $95 \%$ confidence intervals were calculated and presented in the form of Forest plots we generated a league table, which ranks summary estimates in order of the impact of the intervention on the primary outcome measure [10]. In the league table, interventions were ranked from those with the highest effect to the lowest. A stacked bar chart rankogram was also created to represent ranking probabilities and their uncertainty.

\section{Analysis methods}

Data with respect to events and number of patients in individual trials were prepared and entered using NetMetaXL [16], to facilitate completion of a Bayesian network meta-analysis using WinBUGS version 1.4.3 from within Microsoft excel. We used the Markov Chain Monte Carlo method of parameter estimation to obtain posterior estimates of effects. Both vague prior and informative prior results were presented in the Forest Plot. 
Zero cells were adjusted using an adjusted continuity correction factor accounting for potential differences in sample size, centered around 0.5 .

As NetMetaXL is a relatively new tool, we run a separate set of analyses for the same data on GeMTC R package to validate our results with no noticeable differences.

We performed analysis with both fixed effects models and random effects random-effect hierarchical models. For Bayesian computation; detailed statistical approach and diagnostics are provided in Additional file 1.

\section{Assessment of consistency, model fit, and convergence}

In NetMetaXL, 'inconsistency plot' was generated to facilitate visual assessment of conflicts between direct and indirect evidence with limitation in our analysis due to a substantial number of nodes on excel. Heterogeneity for vague and informative priors was provided within the forest plot results \& Monte Carlo error $<5 \%$ of the standard deviation (SD) used to assess convergence.

For GeMTC R package Gelman-Rubin statistics used numerically and graphically to evaluate convergence while deviance information criterion (DIC) was used for determining model fits and the model with smaller DIC value was considered better.

\section{Additional analyses}

In addition to the main analysis we performed three other analysis, the first excluding RCTs with any partial use of hyperosmolar contrast media and in the other two RCTs were divided according to baseline renal profile.

For each of the four analyses we performed sub-analysis excluding studies with zero values as corresponding effects estimates may be subject to numerical instability, generally over-estimate the effect, and that can be observed in the wide associated confidence intervals.

\section{Results}

Study selection

A total of 32,596 study titles were identified in the initial literature search, of which 200 fulfilled criteria for inclusion [4, 5, 7, 17-209] (Fig. 1). Some studies were excluded as some data were partially included or re-analyzed in a
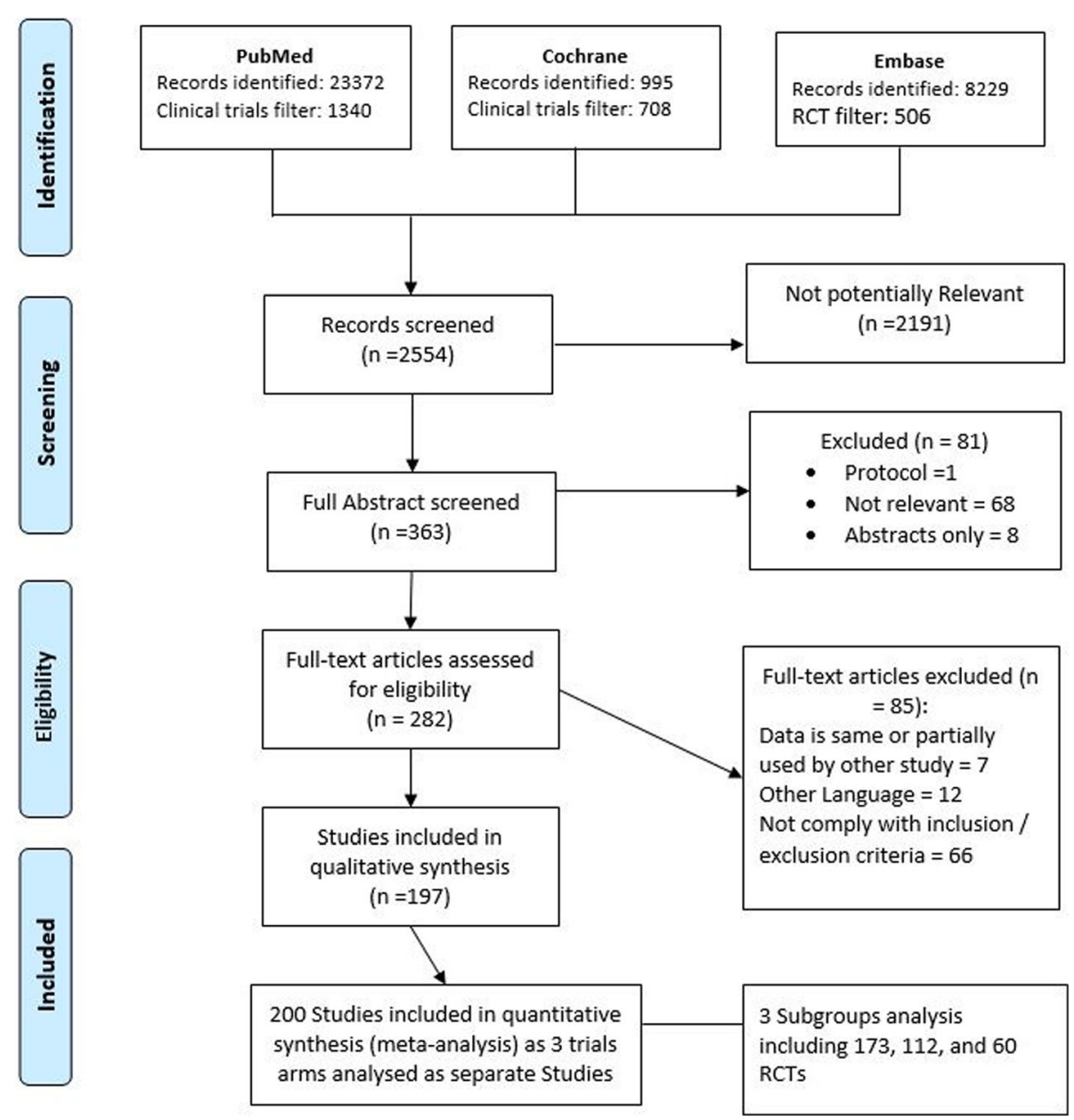

Fig. 1 Flow Diagram 
follow-up study involved in our review [210-215]. A total of 32,399 studies were excluded after remove duplication the most common reasons for exclusions after full examination included observational methodology; different outcome measures, inadequate definition of CI-AKI; unclear evidence of randomization; old studies that did not comply with eligibility criteria for more than one reason [216279]. The twelve studies published in a non-English language included those from centers in Germany [280, 281], China [282-287], Spain [288], France [289], Turkey [290] and Italy [291]. Eight further potentially suitable studies were identified in abstract form only, but were excluded as no full-text article could be identified [292-299].

\section{Study characteristics}

Additional file 2 outlines individual study characteristics (study inclusion and exclusion criteria; procedure performed; baseline renal function; definition of CI-AKI used in the study; contrast medium volume and osmolality). In total, 197studies fulfilled the inclusion criteria, including three which had multiple trial arms requiring separate analyses (Yang 2014, Kumar 2014 \& Chen 2008). A total of 200 comparative analyses were therefore included in our analyses. Coronary angiography accounted for 145 (72.5\%) of the contrast-dependent procedures were. Less frequently reported procedures included contrast-enhanced CT imaging ( $n=16,8 \%)$, peripheral angiography with/without angioplasty and stenting $(n=3,1.5 \%)$ endovascular aneurysm repairs (EVAR) $(\mathrm{n}=1,0.5 \%$ \%). Multiple procedures were included in 35 studies (17.5\%). Low osmolar contrast agents were used in 111 (55.5\%), iso-osmolar agents in 44 studies $(22 \%)$, and hi-osmolar media in 3 studies (1.5\%). Twenty-six (13\%) trials permitted physician discretion in the selection of contrast media, while a further $16(8 \%)$ did not specify the contrast medium utilized. More recent studies we observed better design with an exclusion for patients using alternative CI-AKI prevention interventions from participation or stratified those methods among arms of the trial.

\section{Network structure}

The relationship and comparisons between included studies are demonstrated in the network diagram (Fig. 2). Forty-four interventions are included in this network (Table 1).

\section{Network geometry}

Data from 42,273 patients recruited to 200 trials investigating 44 interventions were included in our analyses; a summary of network characteristics is provided in (Table 2). Nine hundred and forty-six pair-wise comparisons were possible, of which 81 used data from direct comparisons in Additional file 3. The most commonly investigated comparisons are between $\mathrm{N}$-acetylcysteine (NAC) and placebo (36 studies, 8,202patients); and intravenous normal saline and intravenous sodium bicarbonate (24 studies, 5,481patients). The interventions most commonly investigated were NAC, NaHCO3, Statins, Intravenous Hydration (I.V), and placebo or control. The characteristics of individual interventions are outlined in Additional file 3.

\section{Risk of bias}

Risk of bias assessed by two authors (Khalid, Walsh). In case of disagreement, other authors were consulted. Summary for individual studies provided in Additional file 4 while (Fig. 3) shows the risk of bias graph across all studies. Most of the studies demonstrated unclear to low risk of bias while most of the high risk of bias were observed in attrition bias domain. As the outcome measure (CAAKI) is dependent on laboratory results it seems reasonable to assume the risk of bias attributed to blinding of outcome assessment domain was low by default.

\section{Synthesis of results}

The Renal Association, British Cardiovascular Intervention Society and the Royal College of Radiologists among many other medical bodies recommend using intravenous volume expansion as a prevention method for CA-AKI [300]. Thus, we considered intravenous hydration clinically the reference intervention in this analysis, in addition to the node size and the multiple arms within the network which make it very good comparator.

A forest plot was generated to demonstrate odds ratio generated from direct and indirect pair-wise comparisons. Effect estimates, and confidence intervals were included for both vague and informative priors using a random effects model. The overall heterogeneity for the vague prior was 0.54 ( $95 \% \mathrm{CI} 0.41-0.69)$, while that for informative prior was 0.498 (95\% CI 0.366-0.6403). The SUCRA (surface under the cumulative ranking curve) was utilized to generate a stacked bar chart rankogram (Fig. 4). A league table arranging summary of effect estimate, and ranking interventions according to impact on the outcome can be found in Additional file 3 in addition to the Forest Plot, characteristics of interventions and comparisons and analysis specifications. The probabilities of being ranked for the best each intervention is summarized in (Table 3) while the numerical values follow the Rankogram results the list of interventions in the first column follow the league table hierarchy and a good example is Allopurinol which included in 4 studies ranked best in both Rankogram (0.9647) and League Table while Silymarin was 3rd (0.7934) and last respectively and was included in one study. 


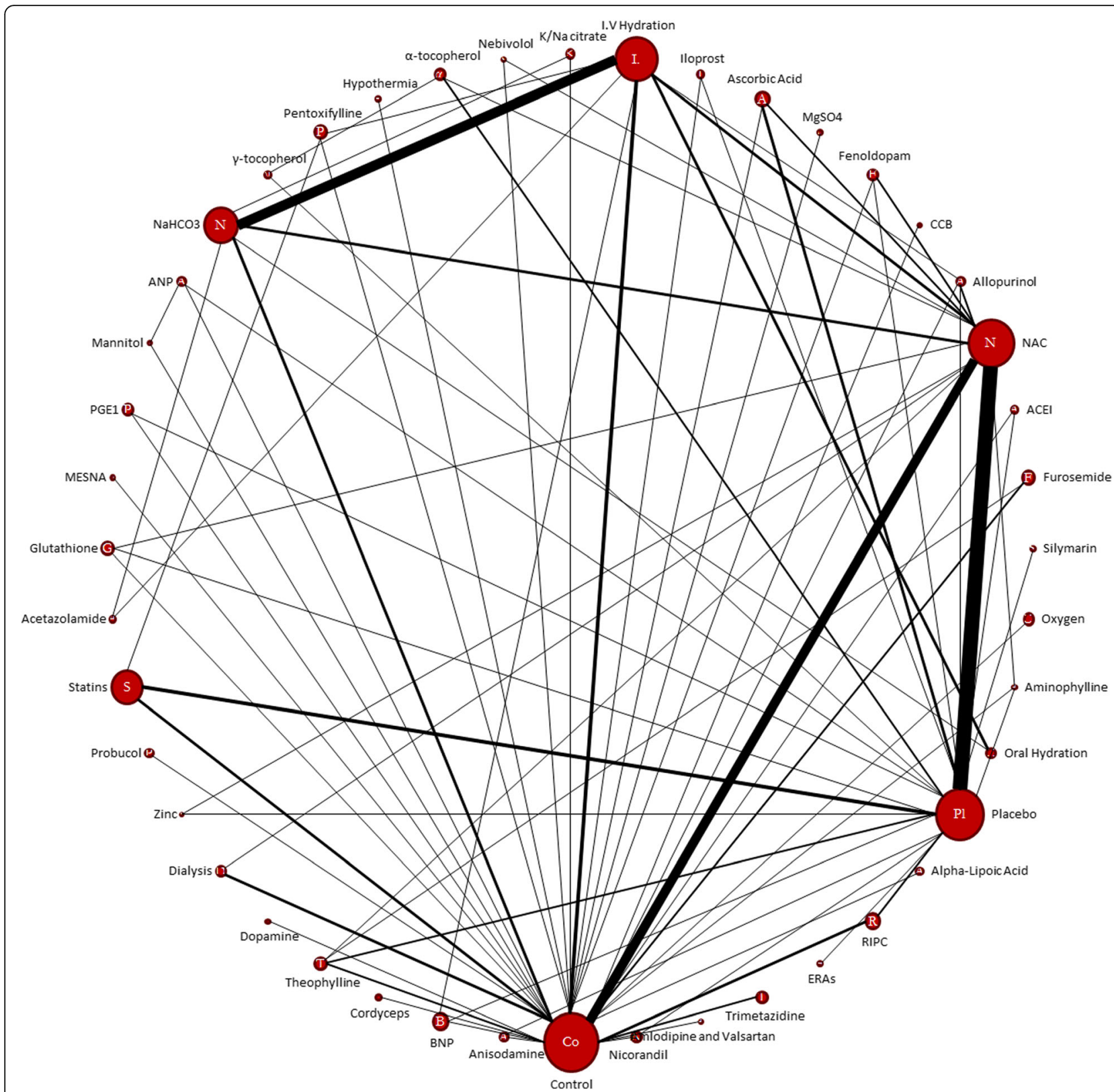

Fig. 2 Network Diagram: The size of each intervention node is proportional to the number of patients included in the trials, while the thickness of interconnecting lines is proportional to the number of pairwise comparisons between any two interventions

\section{Sensitivity analysis}

Flow chart for the main analyses and sub-analyses is included in Additional file 1. From the main analysis 200 RCTs we run sub-analysis that includes 184 RCTS in which we exclude all studies with zero values $(n=7)$. All figures and tables are included in Additional file 3.

The second analysis involved 173 RCTs after excluding studies reporting any use of hyperosmolar contrast media, the sub-analysis without zero values RCTs include 159 RCTS.
Trials with high baseline renal profile were in analysis 3 which includes 112 RCTs and sub-analysis for 105 RCTS. The 4th analysis includes 60 and 53 RCTs respectively. Analysis specifications, figures and tables provided in Additional file 5, Additional file 6 and Additional file 7.

When interpreting sub-analyses results in conventional direct pairwise comparisons the main effect results from the size of the excluded studies because there is no exclusion for interventions and they will always be present at both sides of the forest plot. This impact the overall diamond shape effect estimates size and confidence 
Table 1 Interventions within Network Diagram

\begin{tabular}{|c|c|c|c|}
\hline NO & Drug & Abbreviation & Patients \\
\hline 1 & I.V Hydration & I.V & 5136 \\
\hline 2 & Statins & Sta & 3040 \\
\hline 3 & Furosemide & Fur & 554 \\
\hline 4 & NAC & NAC & 6095 \\
\hline 5 & Trimetazidine & Tri & 352 \\
\hline 6 & $\mathrm{NaHCO} 3$ & $\mathrm{NaH}$ & 3393 \\
\hline 7 & PGE1 & PGE & 304 \\
\hline 8 & $\mathrm{MgSO} 4$ & MgS & 62 \\
\hline 9 & Pentoxifylline & Pen & 438 \\
\hline 10 & Placebo & $\mathrm{Pla}$ & 7044 \\
\hline 11 & Control & Con & 9120 \\
\hline 12 & Allopurinol & All & 204 \\
\hline 13 & BNP & BNP & 744 \\
\hline 14 & Probucol & Pro & 198 \\
\hline 15 & a-tocopherol & $a-t$ & 312 \\
\hline 16 & $\gamma$-tocopherol & $\gamma-\mathrm{t}$ & 102 \\
\hline 17 & Oxygen & Oxy & 346 \\
\hline 18 & Amlodipine and Valsartan & Aml & 45 \\
\hline 19 & KNNa citrate & $\mathrm{K} / \mathrm{N}$ & 203 \\
\hline 20 & Nicorandil & $\mathrm{Nic}$ & 291 \\
\hline 21 & Ascorbic Acid & Asc & 552 \\
\hline 22 & Alpha-Lipoic Acid & Alp & 139 \\
\hline 23 & Oral Hydration & Ora & 254 \\
\hline 24 & Nebivolol & Neb & 40 \\
\hline 25 & Anisodamine & Ani & 192 \\
\hline 26 & RIPC & RIP & 608 \\
\hline 27 & Theophylline & The & 384 \\
\hline 28 & Hypothermia & Hyp & 58 \\
\hline 29 & Glutathione & Glu & 421 \\
\hline 30 & MESNA & MES & 51 \\
\hline 31 & ACEl & $A C$ & 129 \\
\hline 32 & Aminophylline & Ami & 45 \\
\hline 33 & Iloprost & llo & 118 \\
\hline 34 & Acetazolamide & Ace & 94 \\
\hline 35 & ANP & ANP & 202 \\
\hline 36 & Zinc & Zin & 18 \\
\hline 37 & Dialysis & Dia & 293 \\
\hline 38 & Fenoldopam & $\mathrm{Fe}$ & 333 \\
\hline 39 & ERAs & ER & 77 \\
\hline 40 & $C C B$ & CC & 42 \\
\hline 41 & Dopamine & Do & 48 \\
\hline 42 & Mannitol & $\mathrm{Ma}$ & 35 \\
\hline 43 & Cordyceps & Co & 88 \\
\hline 44 & Silymarin & $\mathrm{Si}$ & 69 \\
\hline
\end{tabular}

ACEI Angiotensin Converting-Enzyme Inhibitor, ANP Atrial Natriuretic Peptide, BNP B-Type Natriuretic Peptide, CCB Calcium Channels Blockers, Cl-AKI Contrast Induced Acute Kidney Injury, CIN Contrast Induced Nephropathy, ERAs Endothelin Receptor Antagonism, MESNA 2-Mercaptoethane Sulfonate Sodium MgSo4 Magnesium Sulphate, NAC N-acetyl cysteine, NaHco3 Sodium Bicarbonate, PGE1 Prostaglandin E1, RIPC Remote Ischemic Preconditioning
Table 2 Network Characteristics

\begin{tabular}{ll}
\hline Characteristic & Number \\
\hline Number of Interventions & 44 \\
Number of Studies & 200 \\
Total Number of Patients in Network & 42,273 \\
Total Number of Events in Network & 4602 \\
Total Possible Pairwise Comparisons & 946 \\
Total Number Pairwise Comparisons with Direct Data & 81 \\
Number of Two-arm Studies & 179 \\
Number of Multi-Arms Studies & 21 \\
Number of Studies with No Zero Events & 184 \\
Number of Studies With At Least One Zero Event & 16 \\
Number of Studies with All Zero Events & 2 \\
\hline
\end{tabular}

interval will either shift towards one treatment or touching the line of no effect indicating no superiority for any intervention. This is different in Network Meta-analysis in which we can see changes in connections dynamic (Network Diagram) and interventions numbers represented by node sizes and number of connections between them both can be affected or totally removed by the excluding studies. In the latter case the Network Diagram and characteristics of interventions and comparisons provide detailed visualization to help compare the main vs sub-analysis. In Additional file 3, Additional file 5, Additional file 6 and Additional file 7 we detailed all excluded studies, the affected interventions, Network Diagrams and the characteristics of the interventions and comparisons.

\section{Assessment of consistency}

An 'inconsistency plot' (Fig. 5) was generated to assess inconsistency. Inconsistency in network meta-analysis is similar to heterogeneity in conventional meta-analysis but consistency concerns the relation between the treatments whereas heterogeneity concerns the variation between trials within a pairwise comparison between two treatments. Inconsistency is caused by imbalances in the distribution of effect modifiers in the direct and indirect evidence. Effects modifiers in this large sample include but are not limited to patient factors, drug interactions, contrast media volume and type and renal function preintervention. Inevitably, some modifiers exist that cannot be completely eliminated in large multi-treatment network meta-analysis, leading to some inconsistency, indicating a need for careful interpretation of the results [301]. The consistency plot shows individual data points' posterior mean deviance contributions for the consistency model (horizontal axis) and the unrelated mean effects model (vertical axis) along with the line of equality. In our analysis, the main limitation is excel inability to handle a large amount of nodes. However, there should be a consideration 


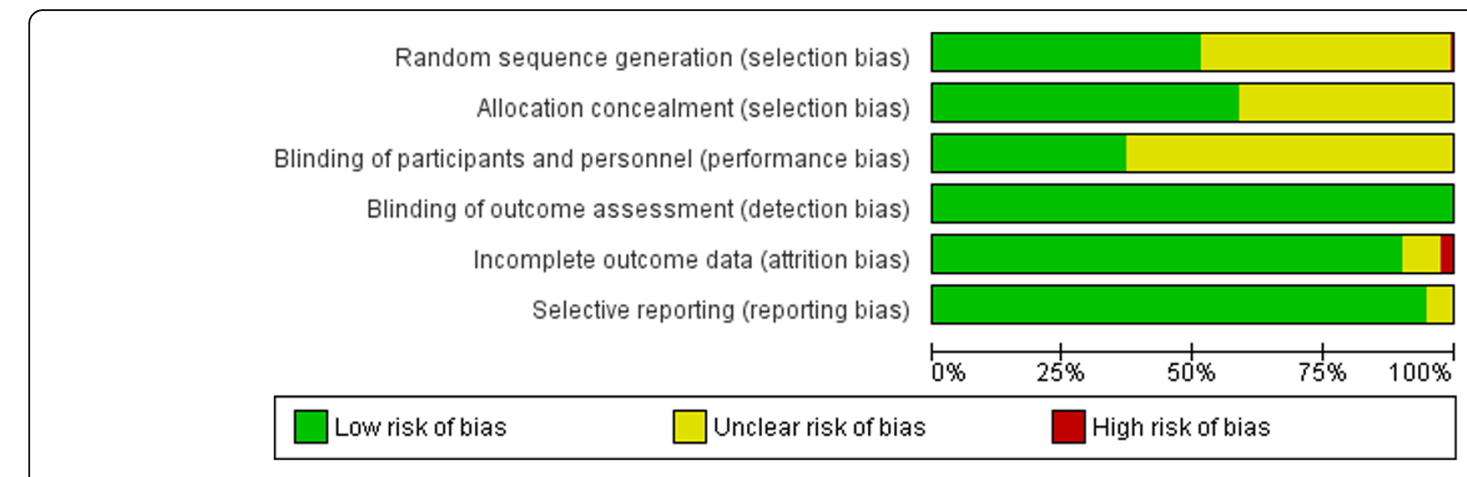

Fig. 3 Risk of Bias Graph

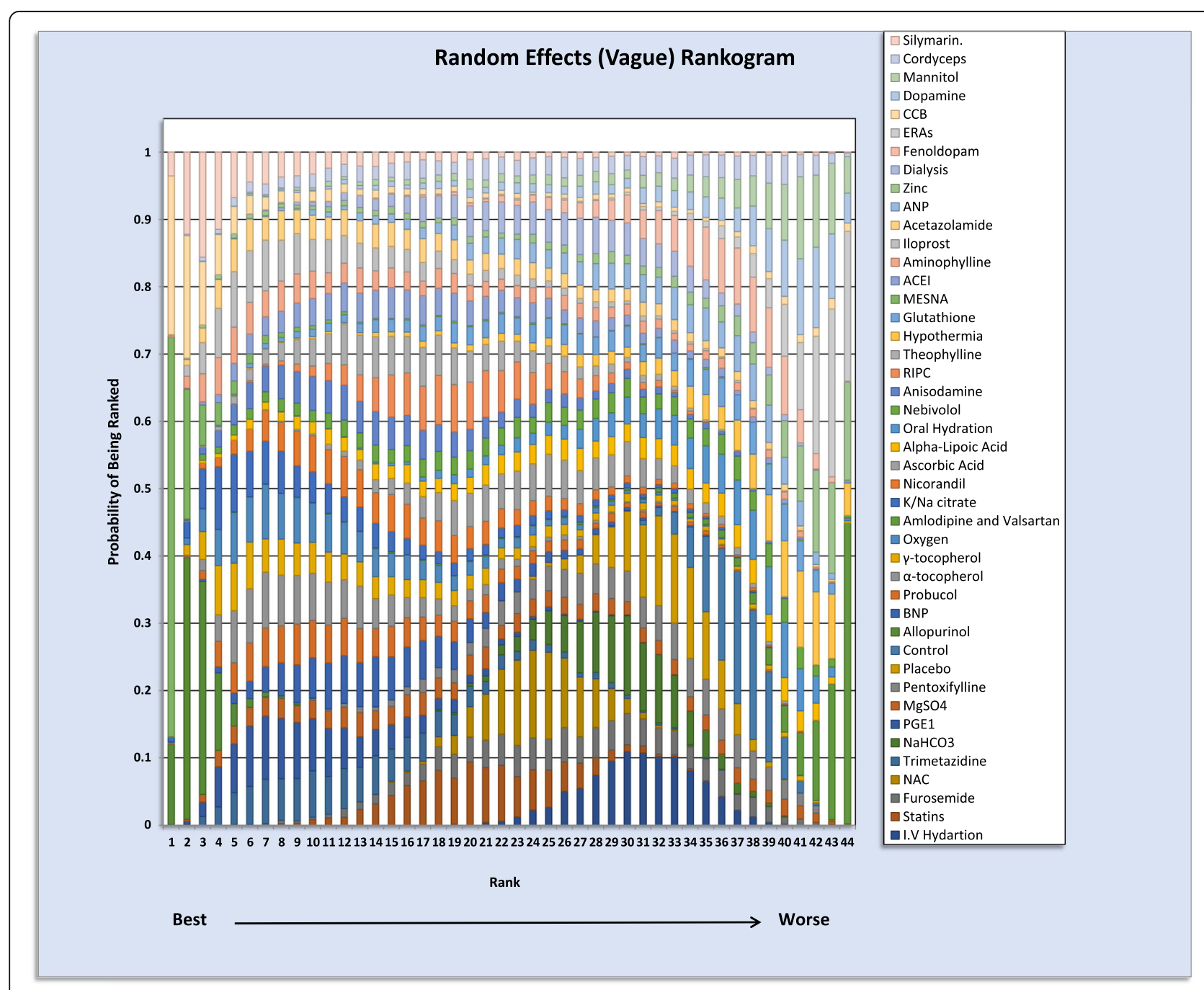

Fig. 4 Rankogram: ranking the interventions for the probability of being the best, the interventions are colour coded; the first column represents the chance of being first best and 2 nd column is the chance of being 2 nd best and so on. i.e. the first column represent the chance of being first best cmparing all interventions out of $100 \%$ and the second represent the chance of being second best out of $100 \%$ up to last column in this case number 44 (nuber of interventions); the overall ranking for each treatment is the sum of scores through out the 44 compasrisons. The overall numerical value is presented in Table 3 
Table 3 Interventions ranking the treatments names column follow the league table (which arranges the presentation of summary estimates by ranking the treatments in order of most pronounced impact on the outcome under consideration) the numerical values represents the cumulative results of the probability of being best in which the highest score is 1 or 100\% (see Rankogram)

\begin{tabular}{|c|c|c|c|}
\hline Treatment & SUCRA & Treatment & SUCRA \\
\hline Allopurinol & 0.9647 & $\mathrm{NaHCO} 3$ & 0.3419 \\
\hline MESNA & 0.9427 & Pentoxifylline & 0.3391 \\
\hline PGE1 & 0.7809 & I.V Hydration & 0.3124 \\
\hline a-tocopherol & 0.7614 & Placebo & 0.2694 \\
\hline Oxygen & 0.7527 & Oral Hydration & 0.2517 \\
\hline KNa citrate & 0.7469 & Hypothermia & 0.2021 \\
\hline Trimetazidine & 0.7151 & Control & 0.1658 \\
\hline Probucol & 0.7042 & Amlodipine and Valsartan & 0.05485 \\
\hline Y-tocopherol & 0.689 & ACEI & 0.5783 \\
\hline BNP & 0.6767 & Aminophylline & 0.6593 \\
\hline Anisodamine & 0.6594 & lloprost & 0.7481 \\
\hline Nicorandil & 0.6442 & Acetazolamide & 0.6242 \\
\hline Theophylline & 0.629 & ANP & 0.3291 \\
\hline RIPC & 0.5692 & Zinc & 0.198 \\
\hline Statins & 0.5497 & Dialysis & 0.4319 \\
\hline $\mathrm{MgSO} 4$ & 0.5177 & Fenoldopam & 0.2296 \\
\hline NAC & 0.4592 & ERAs & 0.06734 \\
\hline Nebivolol & 0.4543 & $C C B$ & 0.7249 \\
\hline Ascorbic Acid & 0.4433 & Dopamine & 0.1916 \\
\hline Alpha-Lipoic Acid & 0.4322 & Mannitol & 0.1905 \\
\hline Furosemide & 0.4027 & Cordyceps & 0.4459 \\
\hline Glutathione & 0.3554 & Silymarin & 0.7934 \\
\hline Analysis & \multicolumn{3}{|c|}{ Random Effects (Vague) } \\
\hline
\end{tabular}
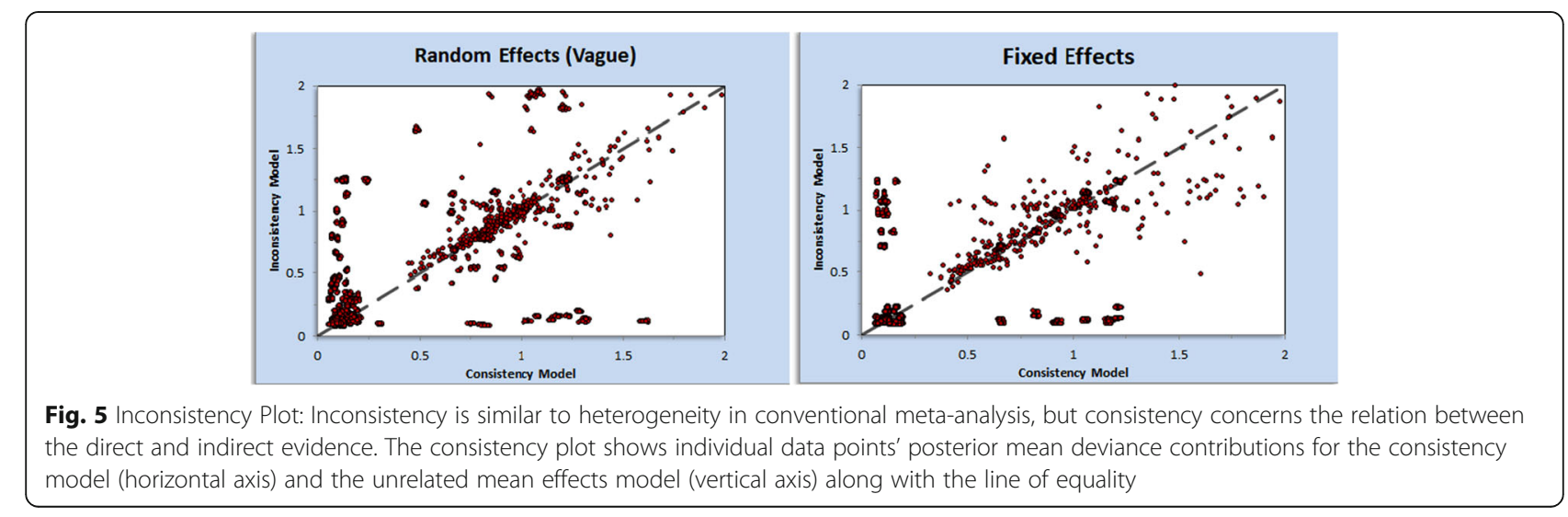

Fig. 5 Inconsistency Plot: Inconsistency is similar to heterogeneity in conventional meta-analysis, but consistency concerns the relation between the direct and indirect evidence. The consistency plot shows individual data points' posterior mean deviance contributions for the consistency model (horizontal axis) and the unrelated mean effects model (vertical axis) along with the line of equality of individual pairwise comparisons effect estimates generated within the forest plot.

In GeMTC R analyses $\mathrm{I}^{2}$ statistics and DIC was much smaller for Random effect indicating less heterogeneity compared with a fixed effect which is expected to provide the nature of the network. Detailed scores are presented in Additional file 1 while Gelman and Rubin's convergence diagnostics were added to corresponded analyses in Additional file 3, Additional file 5, Additional file 6 and Additional file 7.

In general, the main analysis reviled some interesting results with Allopurinol, Prostaglandin E1 (PGE1) \& Oxygen were ranked high with good both statistical and clinical outcomes in relatively fewer number of studies comparing with other interventions studied in larger number of RCTs e.g. NAC, Statins, Hydration, NaHco3 and RIPC. The results were stable throughout different sub analysis considering the changes in network diagram being affected by excluded studies in all 7 networks. The model fitting and the consistency within the network was good considering the large size and it is understandable that it was better fitted in the 7 sub-groups analysis specially after excluding zero values studies. It is very important here to remember in network ranking is the probability of being the best within the interventions and we need to look at the forest plot for each comparison.

\section{Discussion}

\section{Summary of evidence}

This is a systematic review and network meta-analysis (multi-treatment comparison) of studies investigating methods for the prevention of contrast-induced nephropathy. We identified 200 eligible trials, of which 3 had 2 different arms and thus analysed separately. Data from a total of 42,273 patients undergoing 44 different interventions were included. Intravenous hydration ( Nacl) was used as the reference treatment as there is a consensus supported by evidence accepting it as a method of prevention with no clear superiority for other I.V fluids [81]. in our network it was also included in many multiple arms 
RCTs which make it statistically a very good comparator. While only randomized control trials were included, defining the outcome and inclusion criteria, help to minimize the number of effect modifiers at play in different studies, thus minimising inconsistency. However, the assumption of homogeneity should be accepted with caution in light of the large numbers of trials and patients included.

It is very important for readers more familiar with general probability measure in which the value one is assigned to the entire probability space to recognize that SUCRA use posterior probabilities for each treatment to be among the $n$ - best options (cumulative probabilities) thus the sum add to $>1$. The word best referred to the number of times that an intervention ranks first out of the total number of random samples [14] In Rankogram the first column represent the chance of being first best out of $100 \%$ and the second represent the chance of being second best up to last column; the overall ranking for each treatment is the sum and that the reason each treatment probability is calculated out of $100 \%$.

We can generally categorize the 44 ranked interventions in groups. The first group is high ranked interventions with relatively fewer number of studies and this group is mainly for further research consideration despite good design RCTs, good clinical outcomes, and our conscious effort to eliminate the effect of small node effect on the network and the fact we accommodate and accounted for the different in interventions size when calculating the probability but we cannot ignore that this may still play in favour of small studies and we think they deserve another look with larger well-designed trials, this group includes mainly Allopurinol, Prostaglandin E1 (PGE1) \& Oxygen; Allopurinol a xanthine oxidase Inhibitor used for treatment of gout and management of hyperuricemia associated with chemotherapy and was assessed in 4 trials with 204 patients with recent published evidence suggesting some benefits [302] while PGE1 in 4 trails with total 304 patients. Interestingly Oxygen was highly ranked before and after exclusion of zero events studies and the total number of patients was 346 in 2 studies.

The scorned group is the middle group which included in decent number of studies and the interventions in this group with safe and or well tested profile can be used in patient care at the same time continuously evaluated and this group can include RIPC, Statins (which usually in use specially by cardiac and vascular patients), NAC, NaHco3, I.V hydration, Oral hydration and hypothermia. This group needed the physician to consult his local guidelines after evaluating each patient individually and some interventions like hypothermia is not applicable for all patients.
The sub-analyses in our network for was performed after excluding studies with zero events to eliminate favorable effect profile. It produced better statistical results and helped compare the results without the interventions involved in a small number of trials.

\section{Research \& Clinical impact}

For health care providers, the results of this meta-analysis do not suggest changes to current clinical practice. The prevention methods assessed in large studies should be evaluated on a case-by-case basis, bearing in mind the comorbidities, clinical needs and prior risk factors of the individual patient with special consideration to national and local guidelines. Interventions with safe profile and supportive evidence from direct pair-wise meta-analysis can be considered as additional or second-line therapies for CA-AKI prevention. For clinical researchers, the highlyranked treatments with relatively small number of trials merit further examonation in larger RCTs.

\section{Limitations}

One limitation of this meta-analysis is the exclusion of non-English language studies $(n=12)$. The inclusion of these studies may add to the supportive evidence for the use of some interventions, although the effect size of these trials is likely to be minimal in light of the sample sizes in question. Another limitation is the difference in contrast media used which may affect the outcomes; we excluded studies that used hyperosmolar contrast media to minimise this effect with some evidence suggesting similar CIN incidence for iso and low-osmolar CM in coronary angiography patients [303]. In large Network, another consideration is our inability to account for other possible effect modifiers, and our assumptions regarding homogeneity and similarity across a large number of studies thus it is important to look at each intervention ranking through the multiple analyses provided in the supplemnts.

While preparing this network meta-analysis a pairwise meta-analysis was published .comparing $N$-acetylcysteine, sodium bicarbonate, statins and ascorbic acid for CA-AKI reduction [304]. The data was obtained from controlled trials that used intravenous (IV) or intra-arterial contrast. The results of statins plus I.V saline vs I.V saline show clinically but not statistically significant difference. When comparing Sodium bicarbonate to I.V saline it was clinically better, but again the difference was not statistically significant. However Ascorbic acid was better both clinically and statistically vs I.V saline and show no such difference when compared with NAC. A similar result can be observed in our ranking table with $0.5497,0.4433,0.3419$ and 0.3124 probability of being rank for statins, ascorbic acid, Sodium bicarbonate and I.V saline consequently. Although direct comparisons results were provided within 
forest plot in our network, we think the results from pairwise reviews is important; the nature of conventional meta-analysis prevent utilization of multiple arms trials and creating indirect comparison but it can be used to look at sections of more comprehensive network-metaanalysis in addition to the fact that It is more flexible in terms of subgroup analysis and thus assessment of effects modifiers e.g. type of contrast media in this case.

\section{Conclusion}

This systematic review and network meta-analysis provide a comprehensive analysis of currently utilized CAAKI prevention interventions. Results arising from this network identified some highly-ranked interventions throughout analyses and sub-analyses (e.g., Allopurinol, PGE1 \& Oxygen) which were included in small number of trials and merit further examination on a larger scale in the context of a well-designed RCTs.

\section{Additional files}

Additional file 1: Analysis flow chart and statistical approach. (DOCX $125 \mathrm{~kb}$ )

Additional file 2: Studies characteristics. (DOCX $889 \mathrm{~kb}$ )

Additional file 3: Main Analysis 200-184 RCTs. (DOCX 46108 kb)

Additional file 4: Risk of Bias Table. (DOCX $1056 \mathrm{~kb}$ )

Additional file 5: Excluding hyperosmolar 173-159 RCTs. (DOCX 41962 kb)

Additional file 6: High Baseline Renal Profile 112-105 RCTs. (DOCX 32278 kb)

Additional file 7: Normal Baseline Renal Profile 60-53 RCTs. (DOCX 16081 kb)

\section{Abbreviations}

ACEl: Angiotensin Converting-Enzyme Inhibitor; ANP: Atrial Natriuretic Peptide; BNP: B-Type Natriuretic Peptide; CCB: Calcium Channels Blockers; ClAKI: Contrast Induced Acute Kidney Injury; CIN: Contrast Induced Nephropathy; CM: Contrast Media; ERAs: Endothelin Receptor Antagonism; MESNA: 2-Mercaptoethane Sulfonate Sodium; MgSo4: Magnesium Sulphate; NAC: N-acetyl cysteine; NaHco3: Sodium Bicarbonate; PGE1: Prostaglandin E1; RCT: Randomise Control Trails; RIPC: Remote Ischemic Preconditioning

\section{Acknowledgements}

We acknowledge Ms. Geraldine Curtin and the staff in the James Hardiman library, NUI Galway, for their kind assistance in acquiring relevant papers and Information.

\section{Funding}

This research was funded by the National University of Ireland Galway.

\section{Availability of data and materials}

N/A (2ndry data from published studies).

\section{Authors' contributions}

KA: Study design, Literature search, figures, data collection, data Analysis, data interpretation and writing. TM: Critical appraisal, review and edit. RC Figures Editing: SM Figures Editing. MT Critical appraisal, review and edit. MK Methodology, statistical data analysis, data interpretation, review and edit. Professor SW: Methodology, literature search, data interpretation Critical appraisal, review, and edit. All authors read and approved the final manuscript.

\section{Ethics approval and consent to participate}

N/A.

\section{Consent for publication}

N/A.

\section{Competing interests}

The authors declare that they have no competing interests.

\section{Publisher's Note}

Springer Nature remains neutral with regard to jurisdictional claims in published maps and institutional affiliations.

\section{Author details}

${ }^{1}$ Lambe Institute for Translational Research, Discipline of Surgery National University of Ireland, Galway, Republic of Ireland. ²Department of Vascular surgery, Galway University Hospital, Galway, Republic of Ireland. ${ }^{3}$ School of Population and Public Health, University of British Columbia, Scientist / Biostatistician, Centre for Health Evaluation and Outcome Sciences (CHEOS), St. Paul's Hospital, Vancouver, Canada. ${ }^{4} \mathrm{HRB}$ Clinical Research Facility Galway, Galway, Republic of Ireland.

Received: 13 November 2017 Accepted: 22 October 2018

Published online: 13 November 2018

\section{References}

1. Mohammed NM, Mahfouz A, Achkar K, Rafie IM, Hajar R. Contrast-induced nephropathy. Heart Views. 2013;14(3):106-16.

2. Goldfarb S, McCullough PA, McDermott J, Gay SB. Contrast-induced acute kidney injury: specialty-specific protocols for interventional radiology, diagnostic computed tomography radiology, and interventional cardiology. Mayo Clin Proc. 2009;84(2):170-9.

3. Goldenberg I, Matetzky S. Nephropathy induced by contrast media: pathogenesis, risk factors and preventive strategies. CMAJ. 2005;172(11):1461-71.

4. Castini D, Lucreziotti S, Bosotti L, Salerno Uriarte D, Sponzilli C, Verzoni A, et al. Prevention of contrast-induced nephropathy: a single center randomized study. Clin Cardiol. 2010;33(3):E63-8.

5. Maioli M, Toso A, Leoncini M, Gallopin M, Tedeschi D, Micheletti C, et al Sodium bicarbonate versus saline for the prevention of contrast-induced nephropathy in patients with renal dysfunction undergoing coronary angiography or intervention. J Am Coll Cardiol. 2008;52(8):599-604.

6. Mehran R, Nikolsky E. Contrast-induced nephropathy: definition, epidemiology, and patients at risk. Kidney Int Suppl. 2006;100:S11-5.

7. Spargias K, Alexopoulos E, Kyrzopoulos S, lokovis P, Greenwood DC, Manginas A, et al. Ascorbic acid prevents contrast-mediated nephropathy in patients with renal dysfunction undergoing coronary angiography or intervention. Circulation. 2004:110(18):2837-42.

8. Tumlin J, Stacul F, Adam A, Becker CR, Davidson C, Lameire N, et al. Pathophysiology of contrast-induced nephropathy. Am J Cardiol. 2006; 98(6A):14K-20K.

9. Wong PC, Li Z, Guo J, Zhang A. Pathophysiology of contrast-induced nephropathy. Int J Cardiol. 2012;158(2):186-92.

10. Ehrmann S, Aronson D, Hinson JS. Contrast-associated acute kidney injury is a myth: yes. Intensive Care Med. 2018;44(1):104-6.

11. Weisbord SD, du Cheryon D. Contrast-associated acute kidney injury is a myth: no. Intensive Care Med. 2018;44(1):107-9.

12. Thorlund K, Druyts E, Toor K, Jansen JP, Mills EJ. Incorporating alternative design clinical trials in network meta-analyses. Clin Epidemiol. 2015;7:29-35

13. Salanti $G$, Higgins JP, Ades $A E$, loannidis JP. Evaluation of networks of randomized trials. Stat Methods Med Res. 2008;17(3):279-301.

14. Salanti G, Ades AE, loannidis JP. Graphical methods and numerical summaries for presenting results from multiple-treatment meta-analysis: an overview and tutorial. J Clin Epidemiol. 2011:64(2):163-71.

15. Hutton B, Salanti G, Caldwell DM, Chaimani A, Schmid CH, Cameron C, et al. The PRISMA extension statement for reporting of systematic reviews incorporating network meta-analyses of health care interventions: checklist and explanations. Ann Intern Med. 2015;162(11):777-84.

16. Brown S, Hutton B, Clifford T, Coyle D, Grima D, Wells G, et al. A Microsoft-excel-based tool for running and critically appraising network meta-analyses_an overview and application of NetMetaXL. Syst Rev. 2014;3:110

17. Abaci O, Arat Ozkan A, Kocas C, Cetinkal G, Sukru Karaca O, Baydar O, et al. Impact of Rosuvastatin on contrast-induced acute kidney injury in patients at high risk for nephropathy undergoing elective angiography. Am J Cardiol. 2015;115(7):867-71. 
18. Adolph E, Holdt-Lehmann B, Chatterjee T, Paschka S, Prott A, Schneider H, et al. Renal insufficiency following radiocontrast exposure trial (REINFORCE): a randomized comparison of sodium bicarbonate versus sodium chloride hydration for the prevention of contrast-induced nephropathy. Coron Artery Dis. 2008;19(6):413-9.

19. Akyuz S, Karaca M, Kemaloglu Oz T, Altay S, Gungor B, Yaylak B, et al. Efficacy of oral hydration in the prevention of contrast-induced acute kidney injury in patients undergoing coronary angiography or intervention. Nephron Clin Pract. 2014;128(1-2):95-100.

20. Albabtain MA, Almasood A, Alshurafah $\mathrm{H}$, Alamri $\mathrm{H}$, Tamim $\mathrm{H}$. Efficacy of ascorbic acid, $\mathrm{N}$-acetylcysteine, or combination of both on top of saline hydration versus saline hydration alone on prevention of contrast-induced nephropathy: a prospective randomized study. J Interv Cardiol. 2013;26(1):90-6.

21. Allagaband S, Tumuluri R, Malik AM, Gupta A, Volkert P, Shalev Y, et al, Prospective randomized study of $\mathrm{N}$-acetylcysteine, fenoldopam, and saline for prevention of radiocontrast-induced nephropathy. Catheter Cardiovasc Interv. 2002;57(3):279-83.

22. Amini M, Salarifar M, Amirbaigloo A, Masoudkabir F, Esfahani F. Nacetylcysteine does not prevent contrast-induced nephropathy after cardiac catheterization in patients with diabetes mellitus and chronic kidney disease: a randomized clinical trial. Trials. 2009;10:45.

23. Angoulvant $D$, Cucherat M, Rioufol G, Finet G, Beaune J, Revel D, et al. Preventing acute decrease in renal function induced by coronary angiography (PRECORD): a prospective randomized trial. Arch Cardiovasc Dis. 2009;102(11):761-7.

24. Aslanger E, Uslu B, Akdeniz C, Polat N, Cizgici Y, Oflaz H. Intrarenal application of $\mathrm{N}$-acetylcysteine for the prevention of contrast medium-induced nephropathy in primary angioplasty. Coron Artery Dis. 2012;23(4):265-70.

25. Baker CS, Wragg A, Kumar S, De Palma R, Baker LR, Knight CJ. A rapid protocol for the prevention of contrast-induced renal dysfunction: the RAPPID study. J Am Coll Cardiol. 2003;41(12):2114-8.

26. Balderramo DC, Verdu MB, Ramacciotti CF, Cremona LS, Lemos PA, Orias M, et al. Renoprotective effect of high periprocedural doses of oral $\mathrm{N}$ acetylcysteine in patients scheduled to undergo a same-day angiography. Rev Fac Cien Med Univ Nac Cordoba. 2004;61(2):13-9.

27. Baskurt M, Okcun B, Abaci O, Dogan GM, Kilickesmez K, Ozkan AA, et al. Nacetylcysteine versus $\mathrm{N}$-acetylcysteine + theophylline for the prevention of contrast nephropathy. Eur J Clin Investig. 2009;39(9):793-9.

28. Berwanger $O$, Cavalcanti AB, Sousa AM, Buehler A, Castello-Junior HJ, Cantarelli MJ, et al. Acetylcysteine for the prevention of renal outcomes in patients with diabetes mellitus undergoing coronary and peripheral vascular angiography: a substudy of the acetylcysteine for contrast-induced nephropathy trial. Circ Cardiovasc Interv. 2013;6(2):139-45.

29. Bidram P, Roghani F, Sanei H, Hedayati Z, Golabchi A, Mousavi M, et al. Atorvastatin and prevention of contrast induced nephropathy following coronary angiography. J Res Med Sci. 2015;20(1):1-6.

30. Bilasy ME, Oraby MA, Ismail HM, Maklady FA. Effectiveness of theophylline in preventing contrast-induced nephropathy after coronary angiographic procedures. J Interv Cardiol. 2012;25(4):404-10.

31. Boscheri A, Weinbrenner C, Botzek B, Reynen K, Kuhlisch E, Strasser RH. Failure of ascorbic acid to prevent contrast-media induced nephropathy in patients with renal dysfunction. Clin Nephrol. 2007;68(5):279-86.

32. Boucek $P$, Havrdova T, Oliyarnyk $O$, Skibova J, Pecenkova V, Pucelikova T, et al. Prevention of contrast-induced nephropathy in diabetic patients with impaired renal function: a randomized, double blind trial of sodium bicarbonate versus sodium chloride-based hydration. Diabetes Res Clin Pract. 2013;101(3):303-8.

33. Brar SS, Shen AY, Jorgensen MB, Kotlewski A, Aharonian VJ, Desai N, et al. Sodium bicarbonate vs sodium chloride for the prevention of contrast medium-induced nephropathy in patients undergoing coronary angiography: a randomized trial. JAMA. 2008;300(9):1038-46.

34. Briguori C, Airoldi F, D'Andrea D, Bonizzoni E, Morici N, Focaccio A, et al. Renal insufficiency following contrast media administration trial (REMEDIAL): a randomized comparison of 3 preventive strategies. Circulation. 2007; 115(10):1211-7.

35. Briguori C, Colombo A, Airoldi F, Violante A, Castelli A, Balestrieri P, et al. Nacetylcysteine versus fenoldopam mesylate to prevent contrast agentassociated nephrotoxicity. J Am Coll Cardiol. 2004:44(4):762-5.

36. Briguori C, Manganelli F, Scarpato P, Elia PP, Golia B, Riviezzo G, et al. Acetylcysteine and contrast agent-associated nephrotoxicity. J Am Coll Cardiol. 2002;40(2):298-303.
37. Brueck M, Cengiz H, Hoeltgen R, Wieczorek M, Boedeker RH, Scheibelhut $\mathrm{C}$, et al. Usefulness of $\mathrm{N}$-acetylcysteine or ascorbic acid versus placebo to prevent contrast-induced acute kidney injury in patients undergoing elective cardiac catheterization: a single-center prospective, randomized, double-blind, placebo-controlled trial. J Invasive Cardiol. 2013;25(6):276-83.

38. Burns KE, Priestap F, Martin C. N-acetylcysteine in critically ill patients undergoing contrast-enhanced computed tomography: a randomized trial. Clin Nephrol. 2010;74(4):323-6.

39. Carbonell N, Blasco M, Sanjuan R, Perez-Sancho E, Sanchis J, Insa L, et al. Intravenous $\mathrm{N}$-acetylcysteine for preventing contrast-induced nephropathy: a randomised trial. Int J Cardiol. 2007;115(1):57-62.

40. Carbonell N, Sanjuan R, Blasco M, Jorda A, Miguel A. N-acetylcysteine: shortterm clinical benefits after coronary angiography in high-risk renal patients. Rev Esp Cardiol. 2010;63(1):12-9.

41. Chen SL, Zhang J, Yei F, Zhu Z, Liu Z, Lin S, et al. Clinical outcomes of contrastinduced nephropathy in patients undergoing percutaneous coronary intervention: a prospective, multicenter, randomized study to analyze the effect of hydration and acetylcysteine. Int J Cardiol. 2008:126(3):407-13.

42. Cho R, Javed N, Traub D, Kodali S, Atem F, Srinivasan V. Oral hydration and alkalinization is noninferior to intravenous therapy for prevention of contrast-induced nephropathy in patients with chronic kidney disease. J Interv Cardiol. 2010;23(5):460-6.

43. Cicek M, Yildirir A, Okyay K, Yazici AC, Aydinalp A, Kanyilmaz S, et al. Use of alpha-lipoic acid in prevention of contrast-induced nephropathy in diabetic patients. Ren Fail. 2013;35(5):748-53.

44. Coyle LC, Rodriguez A, Jeschke RE, Simon-Lee A, Abbott KC, Taylor AJ. Acetylcysteine In Diabetes (AID): a randomized study of acetylcysteine for the prevention of contrast nephropathy in diabetics. Am Heart J. 2006; 151(5):1032 e9-12.

45. Durham JD, Caputo C, Dokko J, Zaharakis T, Pahlavan M, Keltz J, et al. A randomized controlled trial of $\mathrm{N}$-acetylcysteine to prevent contrast nephropathy in cardiac angiography. Kidney Int. 2002;62(6):2202-7.

46. Dussol B, Morange S, Loundoun A, Auquier P, Berland Y. A randomized trial of saline hydration to prevent contrast nephropathy in chronic renal failure patients. Nephrol Dial Transplant. 2006:21(8):2120-6.

47. Dvorsak B, Kanic V, Ekart R, Bevc S, Hojs R. Ascorbic acid for the prevention of contrast-induced nephropathy after coronary angiography in patients with chronic renal impairment: a randomized controlled trial. Ther Apher Dial. 2013;17(4):384-90.

48. Efrati S, Dishy V, Averbukh M, Blatt A, Krakover R, Weisgarten J, et al. The effect of $\mathrm{N}$-acetylcysteine on renal function, nitric oxide, and oxidative stress after angiography. Kidney Int. 2003;64(6):2182-7.

49. Er F, Nia AM, Dopp H, Hellmich M, Dahlem KM, Caglayan E, et al. Ischemic preconditioning for prevention of contrast medium-induced nephropathy: randomized pilot RenPro trial (renal protection trial). Circulation. 2012:126(3):296-303.

50. Erley CM, Duda SH, Rehfuss D, Scholtes B, Bock J, Muller C, et al. Prevention of radiocontrast-media-induced nephropathy in patients with pre-existing renal insufficiency by hydration in combination with the adenosine antagonist theophylline. Nephrol Dial Transplant. 1999:14(5):1146-9.

51. Erol T, Tekin A, Katircibasi MT, Sezgin N, Bilgi M, Tekin G, et al. Efficacy of allopurinol pretreatment for prevention of contrast-induced nephropathy: a randomized controlled trial. Int J Cardiol. 2013;167(4):1396-9.

52. Erturk M, Uslu N, Gorgulu S, Akbay E, Kurtulus G, Akturk IF, et al. Does intravenous or oral high-dose $\mathrm{N}$-acetylcysteine in addition to saline prevent contrast-induced nephropathy assessed by cystatin C? Coron Artery Dis. 2014;25(2):111-7.

53. Ferrario F, Barone MT, Landoni G, Genderini A, Heidemperger M, Trezzi M, et al. Acetylcysteine and non-ionic isosmolar contrast-induced nephropathy-a randomized controlled study. Nephrol Dial Transplant. 2009;24(10):3103-7.

54. Firouzi A, Eshraghi A, Shakerian F, Sanati HR, Salehi N, Zahedmehr A, et al. Efficacy of pentoxifylline in prevention of contrast-induced nephropathy in angioplasty patients. Int Urol Nephrol. 2012;44(4):1145-9.

55. Firouzi A, Maadani M, Kiani R, Shakerian F, Sanati HR, Zahedmehr A, et al. Intravenous magnesium sulfate: new method in prevention of contrastinduced nephropathy in primary percutaneous coronary intervention. Int Urol Nephrol. 2015;47(3):521-5.

56. Fung JW, Szeto CC, Chan WW, Kum LC, Chan AK, Wong JT, et al. Effect of Nacetylcysteine for prevention of contrast nephropathy in patients with moderate to severe renal insufficiency: a randomized trial. Am J Kidney Dis. 2004;43(5):801-8. 
57. Gare M, Haviv YS, Ben-Yehuda A, Rubinger D, Bdolah-Abram T, Fuchs S, et al. The renal effect of low-dose dopamine in high-risk patients undergoing coronary angiography. J Am Coll Cardiol. 1999;34(6):1682-8.

58. Geng W, Fu XH, Gu XS, Wang YB, Wang XC, Li W, et al. Preventive effects of anisodamine against contrast-induced nephropathy in type 2 diabetics with renal insufficiency undergoing coronary angiography or angioplasty. Chin Med J. 2012;125(19):3368-72

59. Goldenberg I, Shechter M, Matetzky S, Jonas M, Adam M, Pres H, et al. Oral acetylcysteine as an adjunct to saline hydration for the prevention of contrastinduced nephropathy following coronary angiography. A randomized controlled trial and review of the current literature. Eur Heart J. 2004;25(3):212-8.

60. Gomes VO, Lasevitch R, Lima VC, Brito FS Jr, Perez-Alva JC, Moulin B, et al. Hydration with sodium bicarbonate does not prevent contrast nephropathy: a multicenter clinical trial. Arq Bras Cardiol. 2012;99(6):1129-34.

61. Gomes VO, Poli de Figueredo CE, Caramori P, Lasevitch R, Bodanese LC, Araujo A, et al. N-acetylcysteine does not prevent contrast induced nephropathy after cardiac catheterisation with an ionic low osmolality contrast medium: a multicentre clinical trial. Heart. 2005;91(6):774-8.

62. Gu GQ, Lu R, Cui W, Liu F, Zhang Y, Yang XH, et al. Low-dose furosemide administered with adequate hydration reduces contrast-induced nephropathy in patients undergoing coronary angiography. Cardiology. 2013;125(2):69-73.

63. Gulel O, Keles T, Eraslan H, Aydogdu S, Diker E, Ulusoy V. Prophylactic acetylcysteine usage for prevention of contrast nephropathy after coronary angiography. J Cardiovasc Pharmacol. 2005;46(4):464-7.

64. Gunebakmaz O, Kaya MG, Koc F, Akpek M, Kasapkara A, Inanc MT, et al. Does nebivolol prevent contrast-induced nephropathy in humans? Clin Cardiol. 2012;35(4):250-4.

65. Gupta RK, Kapoor A, Tewari S, Sinha N, Sharma RK. Captopril for prevention of contrast-induced nephropathy in diabetic patients: a randomised study. Indian Heart J. 1999;51(5):521-6.

66. Hafiz AM, Jan MF, Mori N, Shaikh F, Wallach J, Bajwa T, et al. Prevention of contrast-induced acute kidney injury in patients with stable chronic renal disease undergoing elective percutaneous coronary and peripheral interventions: randomized comparison of two preventive strategies. Catheter Cardiovasc Interv. 2012;79(6):929-37.

67. Han Y, Zhu G, Han L, Hou F, Huang W, Liu H, et al. Short-term rosuvastatin therapy for prevention of contrast-induced acute kidney injury in patients with diabetes and chronic kidney disease. J Am Coll Cardiol. 2014;63(1):62-70.

68. Hashemi M, Kharazi A, Shahidi S. Captopril for prevention of contrast induced nephropathy in patients undergoing coronary angioplasty: a double blind placebo controlled clinical trial. J Res Med Sci. 2005;10(5):305-8.

69. Heguilen RM, Liste AA, Payaslian M, Ortemberg MG, Albarracin LM, Bernasconi AR. N-acethyl-cysteine reduces the occurrence of contrastinduced acute kidney injury in patients with renal dysfunction: a singlecenter randomized controlled trial. Clin Exp Nephrol. 2013;17(3):396-404.

70. Heng AE, Cellarier E, Aublet-Cuvelier B, Decalf V, Motreff P, Marcaggi X, et al. Is treatment with $\mathrm{N}$-acetylcysteine to prevent contrast-induced nephropathy when using bicarbonate hydration out of date? Clin Nephrol. 2008;70(6):475-84.

71. Hoole SP, Heck PM, Sharples L, Khan SN, Duehmke R, Densem CG, et al. Cardiac remote ischemic preconditioning in coronary stenting (CRISP stent) study: a prospective, randomized control trial. Circulation. 2009;119(6):820-7.

72. Hsu TF, Huang MK, Yu SH, Yen DH, Kao WF, Chen YC, et al. N-acetylcysteine for the prevention of contrast-induced nephropathy in the emergency department. Intern Med. 2012;51(19):2709-14.

73. Huber W, Schipek C, Ilgmann K, Page M, Hennig M, Wacker A, et al. Effectiveness of theophylline prophylaxis of renal impairment after coronary angiography in patients with chronic renal insufficiency. Am J Cardiol. 2003; 91(10):1157-62.

74. Inda-Filho AJ, Caixeta A, Manggini M, Schor N. Do intravenous Nacetylcysteine and sodium bicarbonate prevent high osmolal contrastinduced acute kidney injury? A randomized controlled trial. PLoS One. 2014; 9(9):e107602.

75. Investigators ACT. Acetylcysteine for prevention of renal outcomes in patients undergoing coronary and peripheral vascular angiography: main results from the randomized acetylcysteine for contrast-induced nephropathy trial (ACT). Circulation. 2011;124(11):1250-9.

76. Jaffery Z, Verma A, White CJ, Grant AG, Collins TJ, Grise MA, et al. A randomized trial of intravenous $n$-acetylcysteine to prevent contrast induced nephropathy in acute coronary syndromes. Catheter Cardiovasc Interv. 2012;79(6):921-6.
77. Jo SH, Kim SA, Kim HS, Han SJ, Park WJ, Choi YJ. Alpha-lipoic acid for the prevention of contrast-induced nephropathy in patients undergoing coronary angiography: the ALIVE study - a prospective randomized trial. Cardiology. 2013;126(3):159-66.

78. Jo SH, Koo BK, Park JS, Kang HJ, Cho YS, Kim YJ, et al. Prevention of radiocontrast medium-induced nephropathy using short-term high-dose simvastatin in patients with renal insufficiency undergoing coronary angiography (PROMISS) trial—a randomized controlled study. Am Heart J. 2008;155(3):499 e1-8.

79. Jo SH, Koo BK, Park JS, Kang HJ, Kim YJ, Kim HL, et al. N-acetylcysteine versus AScorbic acid for preventing contrast-induced nephropathy in patients with renal insufficiency undergoing coronary angiography NASPI study-a prospective randomized controlled trial. Am Heart J. 2009;157(3):576-83.

80. Jurado-Roman A, Hernandez-Hernandez F, Garcia-Tejada J, Granda-Nistal C, Molina J, Velazquez M, et al. Role of hydration in contrast-induced nephropathy in patients who underwent primary percutaneous coronary intervention. Am J Cardiol. 2015;115(9):1174-8.

81. Kama A, Yilmaz S, Yaka E, Dervisoglu E, Dogan NO, Erimsah E, et al. Comparison of short-term infusion regimens of $\mathrm{N}$-acetylcysteine plus intravenous fluids, sodium bicarbonate plus intravenous fluids, and intravenous fluids alone for prevention of contrast-induced nephropathy in the emergency department. Acad Emerg Med. 2014;21(6):615-22.

82. Kay J, Chow WH, Chan TM, Lo SK, Kwok OH, Yip A, et al. Acetylcysteine for prevention of acute deterioration of renal function following elective coronary angiography and intervention: a randomized controlled trial. JAMA. 2003:289(5):553-8.

83. Kefer JM, Hanet CE, Boitte S, Wilmotte L, De Kock M. Acetylcysteine, coronary procedure and prevention of contrast-induced worsening of renal function: which benefit for which patient? Acta Cardiol. 2003;58(6):555-60.

84. Khoury Z, Schlicht JR, Como J, Karschner JK, Shapiro AP, Mook WJ, et al. The effect of prophylactic nifedipine on renal function in patients administered contrast media. Pharmacotherapy. 1995;15(1):59-65.

85. Kimmel M, Butscheid M, Brenner S, Kuhlmann U, Klotz U, Alscher DM. Improved estimation of glomerular filtration rate by serum cystatin $C$ in preventing contrast induced nephropathy by $\mathrm{N}$-acetylcysteine or zinc-preliminary results. Nephrol Dial Transplant. 2008;23(4):1241-5.

86. Kinbara T, Hayano T, Ohtani N, Furutani Y, Moritani K, Matsuzaki M. Efficacy of $\mathrm{N}$-acetylcysteine and aminophylline in preventing contrast-induced nephropathy. J Cardiol. 2010;55(2):174-9.

87. Kitzler TM, Jaberi A, Sendlhofer G, Rehak P, Binder C, Petnehazy E, et al. Efficacy of vitamin $\mathrm{E}$ and $\mathrm{N}$-acetylcysteine in the prevention of contrast induced kidney injury in patients with chronic kidney disease: a double blind, randomized controlled trial. Wien Klin Wochenschr. 2012;124(9-10):312-9.

88. Klima T, Christ A, Marana I, Kalbermatter S, Uthoff H, Burri E, et al. Sodium chloride vs. sodium bicarbonate for the prevention of contrast medium-induced nephropathy: a randomized controlled trial. Eur Heart J. 2012;33(16):2071-9.

89. Ko YG, Lee BK, Kang WC, Moon JY, Cho YH, Choi SH, et al. Preventive effect of pretreatment with intravenous nicorandil on contrast-induced nephropathy in patients with renal dysfunction undergoing coronary angiography (PRINCIPLE study). Yonsei Med J. 2013;54(4):957-64.

90. Koc F, Ozdemir K, Altunkas F, Celik A, Dogdu O, Karayakali M, et al. Sodium bicarbonate versus isotonic saline for the prevention of contrast-induced nephropathy in patients with diabetes mellitus undergoing coronary angiography and/or intervention: a multicenter prospective randomized study. J Investig Med. 2013;61(5):872-7.

91. Koc F, Ozdemir K, Kaya MG, Dogdu O, Vatankulu MA, Ayhan S, et al. Intravenous $\mathrm{N}$-acetylcysteine plus high-dose hydration versus high-dose hydration and standard hydration for the prevention of contrast-induced nephropathy: CASIS - a multicenter prospective controlled trial. Int J Cardiol. 2012;155(3):418-23.

92. Koch JA, Plum J, Grabensee B, Modder U. Prostaglandin E1: a new agent for the prevention of renal dysfunction in high risk patients caused by radiocontrast media? PGE1 study group. Nephrol Dial Transplant. 2000;15(1):43-9.

93. Kong DG, Hou YF, Ma LL, Yao DK, Wang LX. Comparison of oral and intravenous hydration strategies for the prevention of contrast-induced nephropathy in patients undergoing coronary angiography or angioplasty: a randomized clinical trial. Acta Cardiol. 2012;67(5):565-9.

94. Kooiman J, Sijpkens YW, de Vries JP, Brulez HF, Hamming JF, van der Molen AJ, et al. A randomized comparison of 1-h sodium bicarbonate hydration versus standard peri-procedural saline hydration in patients with chronic kidney disease undergoing intravenous contrast-enhanced computerized tomography. Nephrol Dial Transplant. 2014;29(5):1029-36. 
95. Kooiman J, Sijpkens YW, van Buren M, Groeneveld JH, Ramai SR, van der Molen AJ, et al. Randomised trial of no hydration vs. sodium bicarbonate hydration in patients with chronic kidney disease undergoing acute computed tomography-pulmonary angiography. J Thromb Haemost. 2014; 12(10):1658-66.

96. Kotlyar E, Keogh AM, Thavapalachandran S, Allada CS, Sharp J, Dias L, et al. Prehydration alone is sufficient to prevent contrast-induced nephropathy after day-only angiography procedures - a randomised controlled trial. Heart Lung Circ. 2005;14(4):245-51.

97. Kumar A, Bhawani G, Kumari N, Murthy KS, Lalwani V, Raju CN. Comparative study of renal protective effects of allopurinol and $\mathrm{N}$-acetyl-cysteine on contrast induced nephropathy in patients undergoing cardiac catheterization. J Clin Diagn Res. 2014;8(12):HC03-7.

98. Kurnik BR, Allgren RL, Genter FC, Solomon RJ, Bates ER, Weisberg LS. Prospective study of atrial natriuretic peptide for the prevention of radiocontrast-induced nephropathy. Am J Kidney Dis. 1998;31(4):674-80.

99. Kurnik BR, Weisberg LS, Cuttler IM, Kurnik PB. Effects of atrial natriuretic peptide versus mannitol on renal blood flow during radiocontrast infusion in chronic renal failure. J Lab Clin Med. 1990;116(1):27-36.

100. Lavi S, D'Alfonso S, Diamantouros P, Camuglia A, Garg P, Teefy P, et al. Remote ischemic postconditioning during percutaneous coronary interventions: remote ischemic postconditioning-percutaneous coronary intervention randomized trial. Circ Cardiovasc Interv. 2014;7(2):225-32.

101. Lawlor DK, Moist L, DeRose G, Harris KA, Lovell MB, Kribs SW, et al. Prevention of contrast-induced nephropathy in vascular surgery patients. Ann Vasc Surg. 2007;21(5):593-7.

102. Lee SW, Kim WJ, Kim YH, Park SW, Park DW, Yun SC, et al. Preventive strategies of renal insufficiency in patients with diabetes undergoing intervention or arteriography (the PREVENT trial). Am J Cardiol. 2011;107(10):1447-52.

103. Lehnert T, Keller E, Gondolf K, Schaffner T, Pavenstadt H, Schollmeyer P. Effect of haemodialysis after contrast medium administration in patients with renal insufficiency. Nephrol Dial Transplant. 1998;13(2):358-62.

104. Leoncini M, Toso A, Maioli M, Tropeano F, Villani S, Bellandi F. Early highdose rosuvastatin for contrast-induced nephropathy prevention in acute coronary syndrome: results from the PRATO-ACS study (protective effect of Rosuvastatin and antiplatelet therapy on contrast-induced acute kidney injury and myocardial damage in patients with acute coronary syndrome). J Am Coll Cardiol. 2014;63(1):71-9.

105. Li G, Yin L, Liu T, Zheng X, Xu G, Xu Y, et al. Role of probucol in preventing contrast-induced acute kidney injury after coronary interventional procedure. Am J Cardiol. 2009;103(4):512-4.

106. Li W, Fu X, Wang Y, Li X, Yang Z, Wang X, et al. Beneficial effects of highdose atorvastatin pretreatment on renal function in patients with acute STsegment elevation myocardial infarction undergoing emergency percutaneous coronary intervention. Cardiology. 2012;122(3):195-202.

107. Li WH, Li DY, Qian WH, Liu JL, Xu TD, Zhu H, et al. Prevention of contrastinduced nephropathy with prostaglandin E1 in high-risk patients undergoing percutaneous coronary intervention. Int Urol Nephrol. 2014;46(4):781-6.

108. Li XM, Cong HL, Li TT, He LJ, Zhou YJ. Impact of benazepril on contrastinduced acute kidney injury for patients with mild to moderate renal insufficiency undergoing percutaneous coronary intervention. Chin Med J. 2011;124(14):2101-6.

109. Ludwig U, Riedel MK, Backes M, Imhof A, Muche R, Keller F. MESNA (sodium 2-mercaptoethanesulfonate) for prevention of contrast medium-induced nephrotoxicity - controlled trial. Clin Nephrol. 2011;75(4):302-8.

110. Luo SJ, Zhou YJ, Shi DM, Ge HL, Wang JL, Liu RF. Remote ischemic preconditioning reduces myocardial injury in patients undergoing coronary stent implantation. Can J Cardiol. 2013;29(9):1084-9.

111. Luo $Y$, Wang $X$, Ye $Z$, Lai $Y$, Yao $Y$, Li J, et al. Remedial hydration reduces the incidence of contrast-induced nephropathy and short-term adverse events in patients with ST-segment elevation myocardial infarction: a single-center, randomized trial. Intern Med. 2014;53(20):2265-72.

112. MacNeill BD, Harding SA, Bazari H, Patton KK, Colon-Hernadez P, DeJoseph D, et al. Prophylaxis of contrast-induced nephropathy in patients undergoing coronary angiography. Catheter Cardiovasc Interv. 2003;60(4):458-61.

113. Maioli M, Toso A, Leoncini M, Micheletti C, Bellandi F. Effects of hydration in contrast-induced acute kidney injury after primary angioplasty: a randomized, controlled trial. Circ Cardiovasc Interv. 2011;4(5):456-62.

114. Malhis M, Al-Bitar S, Al-Deen ZK. The role of theophylline in prevention of radiocontrast media-induced nephropathy. Saudi J Kidney Dis Transpl. 2010;21(2):276-83.
115. Marenzi G, Assanelli E, Marana I, Lauri G, Campodonico J, Grazi M, et al. Nacetylcysteine and contrast-induced nephropathy in primary angioplasty. N Engl J Med. 2006;354(26):2773-82.

116. Marenzi G, Ferrari C, Marana I, Assanelli E, De Metrio M, Teruzzi G, et al. Prevention of contrast nephropathy by furosemide with matched hydration: the MYTHOS (induced diuresis with matched hydration compared to standard hydration for contrast induced nephropathy prevention) trial. JACC Cardiovasc Interv. 2012;5(1):90-7.

117. Marenzi G, Marana I, Lauri G, Assanelli E, Grazi M, Campodonico J, et al. The prevention of radiocontrast-agent-induced nephropathy by hemofiltration. N Engl J Med. 2003;349(14):1333-40.

118. Markota D, Markota I, Starcevic B, Tomic M, Prskalo Z, Brizic I. Prevention of contrast-induced nephropathy with $\mathrm{Na} / \mathrm{K}$ citrate. Eur Heart J. 2013;34(30):2362-7.

119. Masuda M, Yamada T, Mine T, Morita T, Tamaki S, Tsukamoto Y, et al. Comparison of usefulness of sodium bicarbonate versus sodium chloride to prevent contrast-induced nephropathy in patients undergoing an emergent coronary procedure. Am J Cardiol. 2007;100(5):781-6.

120. Matejka J, Varvarovsky I, Vojtisek P, Herman A, Rozsival V, Borkova V, et al. Prevention of contrast-induced acute kidney injury by theophylline in elderly patients with chronic kidney disease. Heart Vessel. 2010;25(6):536-42.

121. Menting TP, Sterenborg TB, de Waal Y, Donders R, Wever KE, Lemson MS, et al. Remote ischemic preconditioning to reduce contrast-induced nephropathy: a randomized controlled trial. Eur J Vasc Endovasc Surg. 2015;50(4):527-32

122. Merten GJ, Burgess WP, Gray LV, Holleman JH, Roush TS, Kowalchuk GJ, et al. Prevention of contrast-induced nephropathy with sodium bicarbonate: a randomized controlled trial. JAMA. 2004;291(19):2328-34.

123. Miao Y, Zhong Y, Yan H, Li W, Wang BY, Jin J. Alprostadil plays a protective role in contrast-induced nephropathy in the elderly. Int Urol Nephrol. 2013;45(4):1179-85.

124. Miner SE, Dzavik V, Nguyen-Ho P, Richardson R, Mitchell J, Atchison D, et al. $\mathrm{N}$-acetylcysteine reduces contrast-associated nephropathy but not clinical events during long-term follow-up. Am Heart J. 2004;148(4):690-5.

125. Moore NN, Lapsley M, Norden AG, Firth JD, Gaunt ME, Varty K, et al. Does $\mathrm{N}$-acetylcysteine prevent contrast-induced nephropathy during endovascular AAA repair? A randomized controlled pilot study. J Endovasc Ther. 2006;13(5):660-6

126. Morikawa S, Sone T, Tsuboi H, Mukawa H, Morishima I, Uesugi M, et al. Renal protective effects and the prevention of contrast-induced nephropathy by atrial natriuretic peptide. J Am Coll Cardiol. 2009;53(12):1040-6.

127. Motohiro M, Kamihata H, Tsujimoto S, Seno T, Manabe K, Isono T, et al. A new protocol using sodium bicarbonate for the prevention of contrastinduced nephropathy in patients undergoing coronary angiography. Am J Cardiol. 2011;107(11):1604-8.

128. Ng TM, Shurmur SW, Silver M, Nissen LR, O'Leary EL, Rigmaiden RS, et al. Comparison of $\mathrm{N}$-acetylcysteine and fenoldopam for preventing contrastinduced nephropathy (CAFCIN). Int J Cardiol. 2006;109(3):322-8.

129. Ochoa A, Pellizzon G, Addala S, Grines C, Isayenko Y, Boura J, et al. Abbreviated dosing of $\mathrm{N}$-acetylcysteine prevents contrast-induced nephropathy after elective and urgent coronary angiography and intervention. J Interv Cardiol. 2004;17(3):159-65.

130. Oguzhan N, Cilan H, Sipahioglu M, Unal A, Kocyigit I, Kavuncuoglu F, et al. The lack of benefit of a combination of an angiotensin receptor blocker and calcium channel blocker on contrast-induced nephropathy in patients with chronic kidney disease. Ren Fail. 2013;35(4):434-9.

131. Oldemeyer JB, Biddle WP, Wurdeman RL, Mooss AN, Cichowski E, Hilleman DE. Acetylcysteine in the prevention of contrast-induced nephropathy after coronary angiography. Am Heart J. 2003;146(6):E23.

132. Onbasili AO, Yeniceriglu Y, Agaoglu P, Karul A, Tekten T, Akar H, et al. Trimetazidine in the prevention of contrast-induced nephropathy after coronary procedures. Heart. 2007;93(6):698-702.

133. Ozcan EE, Guneri S, Akdeniz B, Akyildiz IZ, Senaslan O, Baris N, et al. Sodium bicarbonate, $\mathrm{N}$-acetylcysteine, and saline for prevention of radiocontrast-induced nephropathy. A comparison of 3 regimens for protecting contrast-induced nephropathy in patients undergoing coronary procedures. A single-center prospective controlled trial. Am Heart J. 2007:154(3):539-44.

134. Ozhan H, Erden I, Ordu S, Aydin M, Caglar O, Basar C, et al. Efficacy of shortterm high-dose atorvastatin for prevention of contrast-induced nephropathy in patients undergoing coronary angiography. Angiology. 2010;61(7):711-4. 
135. Pakfetrat M, Nikoo MH, Malekmakan L, Tabandeh M, Roozbeh J, Nasab MH et al. A comparison of sodium bicarbonate infusion versus normal saline infusion and its combination with oral acetazolamide for prevention of contrast-induced nephropathy: a randomized, double-blind trial. Int Urol Nephrol. 2009;41(3):629-34

136. Patti G, Ricottini E, Nusca A, Colonna G, Pasceri V, D'Ambrosio A, et al. Shortterm, high-dose atorvastatin pretreatment to prevent contrast-induced nephropathy in patients with acute coronary syndromes undergoing percutaneous coronary intervention from the ARMYDA-CIN [atorvastatin for reduction of myocardial damage during angioplasty-contrast-induced nephropathy] trial. Am J Cardiol. 2011;108(1):1-7.

137. Poletti PA, Platon A, De Seigneux S, Dupuis-Lozeron E, Sarasin F, Becker CD, et al. $\mathrm{N}$-acetylcysteine does not prevent contrast nephropathy in patients with renal impairment undergoing emergency $\mathrm{CT}$ : a randomized study. BMC Nephrol. 2013;14:119.

138. Qiao B, Deng J, Li Y, Wang X, Han Y. Rosuvastatin attenuated contrastinduced nephropathy in diabetes patients with renal dysfunction. Int J Clin Exp Med. 2015;8(2):2342-9.

139. Quintavalle C, Fiore D, De Micco F, Visconti G, Focaccio A, Golia B, et al. Impact of a high loading dose of atorvastatin on contrast-induced acute kidney injury. Circulation. 2012;126(25):3008-16.

140. Rahman MM, Haque SS, Rokeya B, Siddique MA, Banerjee SK, Ahsan SA, et al. Trimetazidine in the prevention of contrast induced nephropathy after coronary angiogram. Mymensingh Med J. 2012;21(2):292-9.

141. Rashid ST, Salman M, Myint F, Baker DM, Agarwal S, Sweny P, et al. Prevention of contrast-induced nephropathy in vascular patients undergoing angiography: a randomized controlled trial of intravenous $\mathrm{N}$ acetylcysteine. J Vasc Surg. 2004;40(6):1136-41.

142. Reinecke H, Fobker M, Wellmann J, Becke B, Fleiter J, Heitmeyer C, et al. A randomized controlled trial comparing hydration therapy to additiona hemodialysis or $\mathrm{N}$-acetylcysteine for the prevention of contrast mediuminduced nephropathy: the Dialysis-versus-diuresis (DVD) trial. Clin Res Cardiol. 2007;96(3):130-9.

143. Rohani A. Effectiveness of aminophylline prophylaxis of renal impairment after coronary angiography in patients with chronic renal insufficiency. Indian J Nephrol. 2010;20(2):80-3.

144. Sadat U, Walsh SR, Norden AG, Gillard JH, Boyle JR. Does oral Nacetylcysteine reduce contrast-induced renal injury in patients with peripheral arterial disease undergoing peripheral angiography? A randomized-controlled study. Angiology. 2011;62(3):225-30.

145. Saitoh T, Satoh H, Nobuhara M, Machii M, Tanaka T, Ohtani H, et al. Intravenous glutathione prevents renal oxidative stress after coronary angiography more effectively than oral N-acetylcysteine. Heart Vessel. 2011;26(5):465-72.

146. Sandhu C, Belli AM, Oliveira DB. The role of N-acetylcysteine in the prevention of contrast-induced nephrotoxicity. Cardiovasc Intervent Radiol. 2006:29(3):344-7.

147. Sanei H, Hajian-Nejad A, Sajjadieh-Kajouei A, Nazemzadeh N, Alizadeh N, Bidram $\mathrm{P}$, et al. Short term high dose atorvastatin for the prevention of contrast-induced nephropathy in patients undergoing computed tomography angiography. ARYA Atheroscler. 2014;10(5):252-8.

148. Sar F, Saler T, Ecebay A, Saglam ZA, Ozturk S, Kazancioglu R. The efficacy of n-acetylcysteine in preventing contrast-induced nephropathy in type 2 diabetic patients without nephropathy. J Nephrol. 2010;23(4):478-82.

149. Savaj S, Savoj J, Jebraili I, Sezavar SH. Remote ischemic preconditioning for prevention of contrast-induced acute kidney injury in diabetic patients. Iran J Kidney Dis. 2014;8(6):457-60.

150. Sekiguchi $H$, Ajiro $Y$, Uchida $Y$, Ishida I, Otsuki $H$, Hattori $H$, et al. Oxygen pre-conditioning prevents contrast-induced nephropathy (OPtion CIN study). J Am Coll Cardiol. 2013;62(2):162-3.

151. Seyon RA, Jensen LA, Ferguson IA, Williams RG. Efficacy of N-acetylcysteine and hydration versus placebo and hydration in decreasing contrast-induced renal dysfunction in patients undergoing coronary angiography with or without concomitant percutaneous coronary intervention. Heart Lung. 2007; 36(3):195-204

152. Shehata M. Impact of trimetazidine on incidence of myocardial injury and contrast-induced nephropathy in diabetic patients with renal dysfunction undergoing elective percutaneous coronary intervention. Am J Cardiol. 2014;114(3):389-94.

153. Shehata M, Hamza M. Impact of high loading dose of atorvastatin in diabetic patients with renal dysfunction undergoing elective percutaneous coronary intervention: a randomized controlled trial. Cardiovasc Ther. 2015;33(2):35-41.
154. Shyu KG, Cheng JJ, Kuan P. Acetylcysteine protects against acute renal damage in patients with abnormal renal function undergoing a coronary procedure. J Am Coll Cardiol. 2002;40(8):1383-8.

155. Solomon R, Werner C, Mann D, D'Elia J, Silva P. Effects of saline, mannitol, and furosemide to prevent acute decreases in renal function induced by radiocontrast agents. N Engl J Med. 1994;331(21):1416-20.

156. Spargias K, Adreanides E, Demerouti E, Gkouziouta A, Manginas A, Pavlides $\mathrm{G}$, et al. Iloprost prevents contrast-induced nephropathy in patients with renal dysfunction undergoing coronary angiography or intervention. Circulation. 2009;120(18):1793-9.

157. Spargias K, Adreanides E, Giamouzis G, Karagiannis S, Gouziouta A, Manginas A, et al. Iloprost for prevention of contrast-mediated nephropathy in high-risk patients undergoing a coronary procedure. Results of a randomized pilot study. Eur J Clin Pharmacol. 2006;62(8):589-95.

158. Stone GW, McCullough PA, Tumlin JA, Lepor NE, Madyoon H, Murray P, et al. Fenoldopam mesylate for the prevention of contrast-induced nephropathy: a randomized controlled trial. JAMA. 2003;290(17):2284-91.

159. Stone GW, Vora K, Schindler J, Diaz C, Mann T, Dangas G, et al. Systemic hypothermia to prevent radiocontrast nephropathy (from the COOL-RCN randomized trial). Am J Cardiol. 2011;108(5):741-6.

160. Tamura A, Goto Y, Miyamoto K, Naono S, Kawano Y, Kotoku M, et al. Efficacy of single-bolus administration of sodium bicarbonate to prevent contrastinduced nephropathy in patients with mild renal insufficiency undergoing an elective coronary procedure. Am J Cardiol. 2009;104(7):921-5.

161. Tanaka A, Suzuki Y, Suzuki N, Hirai T, Yasuda N, Miki K, et al. Does Nacetylcysteine reduce the incidence of contrast-induced nephropathy and clinical events in patients undergoing primary angioplasty for acute myocardial infarction? Intern Med. 2011;50(7):673-7.

162. Tasanarong A, Piyayotai D, Thitiarchakul S. Protection of radiocontrast induced nephropathy by vitamin E (alpha tocopherol): a randomized controlled pilot study. J Med Assoc Thail. 2009;92(10):1273-81.

163. Tasanarong A, Vohakiat A, Hutayanon P, Piyayotai D. New strategy of alphaand gamma-tocopherol to prevent contrast-induced acute kidney injury in chronic kidney disease patients undergoing elective coronary procedures. Nephrol Dial Transplant. 2013;28(2):337-44.

164. Tepel M, van der Giet M, Schwarzfeld C, Laufer U, Liermann D, Zidek W. Prevention of radiographic-contrast-agent-induced reductions in renal function by acetylcysteine. N Engl J Med. 2000;343(3):180-4.

165. Thiele H, Hildebrand L, Schirdewahn C, Eitel I, Adams V, Fuernau G, et al. Impact of high-dose $\mathrm{N}$-acetylcysteine versus placebo on contrast-induced nephropathy and myocardial reperfusion injury in unselected patients with ST-segment elevation myocardial infarction undergoing primary percutaneous coronary intervention. The LIPSIA-N-ACC (Prospective, SingleBlind, Placebo-Controlled, Randomized Leipzig Immediate PercutaneouS Coronary Intervention Acute Myocardial Infarction N-ACC) Trial. J Am Coll Cardiol. 2010;55(20):2201-9.

166. Toso A, Maioli M, Leoncini M, Gallopin M, Tedeschi D, Micheletti C, et al. Usefulness of atorvastatin $(80 \mathrm{mg}$ ) in prevention of contrast-induced nephropathy in patients with chronic renal disease. Am J Cardiol. 2010;105(3):288-92.

167. Traub SJ, Mitchell AM, Jones AE, Tang A, O'Connor J, Nelson T, et al. Nacetylcysteine plus intravenous fluids versus intravenous fluids alone to prevent contrast-induced nephropathy in emergency computed tomography. Ann Emerg Med. 2013;62(5):511-20 e25.

168. Trivedi HS, Moore H, Nasr S, Aggarwal K, Agrawal A, Goel P, et al. A randomized prospective trial to assess the role of saline hydration on the development of contrast nephrotoxicity. Nephron Clin Pract. 2003;93(1):C29-34.

169. Tumlin JA, Wang A, Murray PT, Mathur VS. Fenoldopam mesylate blocks reductions in renal plasma flow after radiocontrast dye infusion: a pilot trial in the prevention of contrast nephropathy. Am Heart J. 2002;143(5):894-903.

170. Vasheghani-Farahani A, Sadigh G, Kassaian SE, Khatami SM, Fotouhi A Razavi SA, et al. Sodium bicarbonate in preventing contrast nephropathy in patients at risk for volume overload: a randomized controlled trial. J Nephrol. 2010;23(2):216-23.

171. Vasheghani-Farahani A, Sadigh G, Kassaian SE, Khatami SM, Fotouhi A, Razavi SA, et al. Sodium bicarbonate plus isotonic saline versus saline for prevention of contrast-induced nephropathy in patients undergoing coronary angiography: a randomized controlled trial. Am J Kidney Dis. 2009:54(4):610-8.

172. Vogt B, Ferrari P, Schonholzer C, Marti HP, Mohaupt M, Wiederkehr M, et al. Prophylactic hemodialysis after radiocontrast media in patients with renal insufficiency is potentially harmful. Am J Med. 2001;111(9):692-8. 
173. Wang A, Holcslaw T, Bashore TM, Freed MI, Miller D, Rudnick MR, et al Exacerbation of radiocontrast nephrotoxicity by endothelin receptor antagonism. Kidney Int. 2000;57(4):1675-80.

174. Wang Y, Fu X, Wang X, Jia X, Gu X, Zhang J, et al. Protective effects of anisodamine on renal function in patients with ST-segment elevation myocardial infarction undergoing primary percutaneous coronary intervention. Tohoku J Exp Med. 2011;224(2):91-7.

175. Webb JG, Pate GE, Humphries KH, Buller CE, Shalansky S, Al Shamari A, et al. A randomized controlled trial of intravenous $\mathrm{N}$-acetylcysteine for the prevention of contrast-induced nephropathy after cardiac catheterization: lack of effect. Am Heart J. 2004;148(3):422-9.

176. Weisberg LS, Kurnik PB, Kurnik BR. Dopamine and renal blood flow in radiocontrast-induced nephropathy in humans. Ren Fail. 1993;15(1):61-8.

177. Wrobel W, Sinkiewicz W, Gordon M, Wozniak-Wisniewska A. Oral versus intravenous hydration and renal function in diabetic patients undergoing percutaneous coronary interventions. Kardiol Pol. 2010;68(9):1015-20.

178. Xu X, Zhou Y, Luo S, Zhang W, Zhao Y, Yu M, et al. Effect of remote ischemic preconditioning in the elderly patients with coronary artery disease with diabetes mellitus undergoing elective drug-eluting stent implantation. Angiology. 2014;65(8):660-6.

179. Yamanaka T, Kawai Y, Miyoshi T, Mima T, Takagaki K, Tsukuda S, et al. Remote ischemic preconditioning reduces contrast-induced acute kidney injury in patients with ST-elevation myocardial infarction: a randomized controlled trial. Int J Cardiol. 2015;178:136-41.

180. Yang K, Liu W, Ren W, Lv S. Different interventions in preventing contrastinduced nephropathy after percutaneous coronary intervention. Int Urol Nephrol. 2014;46(9):1801-7.

181. Yavari V, Ostovan MA, Kojuri J, Afshariani R, Hamidian Jahromi A, Roozbeh J, et al. The preventive effect of pentoxifylline on contrast-induced nephropathy: a randomized clinical trial. Int Urol Nephrol. 2014;46(1):41-6.

182. Yeganehkhah MR, Iranirad L, Dorri F, Pazoki S, Akbari H, Miryounesi M, et al. Comparison between three supportive treatments for prevention of contrast-induced nephropathy in high-risk patients undergoing coronary angiography. Saudi J Kidney Dis Transpl. 2014;25(6):1217-23.

183. Yin L, Li G, Liu T, Yuan R, Zheng X, Xu G, et al. Probucol for the prevention of cystatin C-based contrast-induced acute kidney injury following primary or urgent angioplasty: a randomized, controlled trial. Int J Cardiol. 2013; 167(2):426-9.

184. Zhang J, Fu X, Jia X, Fan X, Gu X, Li S, et al. B-type natriuretic peptide for prevention of contrast-induced nephropathy in patients with heart failure undergoing primary percutaneous coronary intervention. Acta Radiol. 2010;51(6):641-8

185. Zhao K, Lin Y, Li YJ, Gao S. Efficacy of short-term cordyceps sinensis for prevention of contrast-induced nephropathy in patients with acute coronary syndrome undergoing elective percutaneous coronary intervention. Int J Clin Exp Med. 2014;7(12):5758-64.

186. Zhou L, Chen H. Prevention of contrast-induced nephropathy with ascorbic acid. Intern Med. 2012;51(6):531-5.

187. Abouzeid SM, ElHossary HE. $\mathrm{Na} / \mathrm{K}$ citrate versus sodium bicarbonate in prevention of contrast-induced nephropathy. Saudi J Kidney Dis Transpl. 2016:27(3):519-25.

188. Arabmomeni M, Najafian J, Abdar Esfahani M, Samadi M, Mirbagher L. Comparison between theophylline, $\mathrm{N}$-acetylcysteine, and theophylline plus $\mathrm{N}$-acetylcysteine for the prevention of contrast-induced nephropathy. ARYA Atheroscler. 2015:11(1):43-9.

189. Balbir Singh G, Ann SH, Park J, Chung HC, Lee JS, Kim ES, et al. Remote ischemic preconditioning for the prevention of contrast-induced acute kidney injury in diabetics receiving elective percutaneous coronary intervention. PLoS One. 2016;11(10):e0164256.

190. Chong E, Poh KK, Lu Q, Zhang JJ, Tan N, Hou XM, et al. Comparison of combination therapy of high-dose oral $\mathrm{N}$-acetylcysteine and intravenous sodium bicarbonate hydration with individual therapies in the reduction of contrast-induced nephropathy during cardiac catheterisation and percutaneous coronary intervention (CONTRAST): a multi-Centre, randomised, controlled trial. Int J Cardiol. 2015;201:237-42.

191. Eshraghi A, Naranji-Sani R, Pourzand H, Vojdanparast M, Morovatfar N, Ramezani J, et al. Pentoxifylline and prevention of contrast-induced nephropathy: is it efficient in patients with myocardial infarction undergoing coronary angioplasty? ARYA atheroscler[Internet]. 2017;12(5):1-5 Available from: http://onlinelibrary.wiley.com/o/cochrane/clcentral/articles/ 737/CN-01298737/frame.html.
192. Fan Y, Wei Q, Cai J, Shi Y, Zhang Y, Yao L, et al. Preventive effect of oral nicorandil on contrast-induced nephropathy in patients with renal insufficiency undergoing elective cardiac catheterization. Heart Vessel. 2016; 31(11):1776-82.

193. Healy DA, Feeley I, Keogh CJ, Scanlon TG, Hodnett PA, Stack AG, et al. Remote ischemic conditioning and renal function after contrast-enhanced CT scan: a randomized trial. Clin Invest Med. 2015;38(3):E110-8.

194. Izani WMW, Darus Z, Yusof Z. Oral N-acetylcysteine in prevention of contrast induced nephropathy following coronary angiogram. Int Med J [Internet]. 2008;15(5):353-61 Available from: http://onlinelibrary.wiley.com/o/cochrane/ clcentral/articles/905/CN-00754905/frame.html.

195. Kai Z, Yongjian L, Sheng G, Yu L. Effect of Dongchongxiacao (Cordyceps) therapy on contrast-induced nephropathy in patients with type 2 diabetes and renal insufficiency undergoing coronary angiography. J Tradit Chin Med. 2015:35(4):422-7.

196. Khosravi A, Dolatkhah M, Hashemi HS, Rostami Z. Preventive effect of atorvastatin $(80 \mathrm{mg}$ ) on contrast-induced nephropathy after angiography in high-risk patients: double-blind randomized clinical trial. Nephrourol Mon. 2016;8(3):e29574.

197. Liu J, Xie Y, He F, Gao Z, Hao Y, Zu X, et al. Recombinant brain natriuretic peptide for the prevention of contrast-induced nephropathy in patients with chronic kidney disease undergoing nonemergent percutaneous coronary intervention or coronary angiography: a randomized controlled trial. Biomed Res Int. 2016;2016:5985327.

198. Liu W, Ming Q, Shen J, Wei Y, Li W, Chen W, et al. Trimetazidine prevention of contrast-induced nephropathy in coronary angiography. Am J Med Sci. 2015;350(5):398-402.

199. Minoo F, Lessan-Pezeshki M, Firouzi A, Nikfarjam S, Gatmiri SM, Ramezanzade E. Prevention of contrast-induced nephropathy with oxygen supplementation: a randomized controlled trial. Iran J Kidney Dis. 2016;10(5):291-8.

200. Nawa T, Nishigaki K, Kinomura Y, Tanaka T, Yamada Y, Kawasaki M, et al. Continuous intravenous infusion of nicorandil for 4 hours before and 24 hours after percutaneous coronary intervention protects against contrast-induced nephropathy in patients with poor renal function. Int J Cardiol. 2015;195:228-34.

201. Nijssen EC, Rennenberg RJ, Nelemans PJ, Essers BA, Janssen MM, Vermeeren $M A$, et al. Prophylactic hydration to protect renal function from intravascular iodinated contrast material in patients at high risk of contrast-induced nephropathy (AMACING): a prospective, randomised, phase 3, controlled, open-label, non-inferiority trial. Lancet. 2017;389(10076):1312-22.

202. Rezaei Y, Khademvatani K, Rahimi B, Khoshfetrat M, Arjmand N, SeyyedMohammadzad $\mathrm{MH}$. Short-term high-dose vitamin E to prevent contras medium-induced acute kidney injury in patients with chronic kidney disease undergoing elective coronary angiography: a randomized placebocontrolled trial. J Am Heart Assoc. 2016;5(3):e002919.

203. Sadineni R, Karthik KR, Swarnalatha G, Das U, Taduri G. N-acetyl cysteine versus allopurinol in the prevention of contrast nephropathy in patients with chronic kidney disease: a randomized controlled trial. Indian J Nephrol. 2017;27(2):93-8.

204. Sedighifard Z, Roghani F, Bidram P, Harandi SA, Molavi S. Silymarin for the prevention of contrast-induced nephropathy: a placebo-controlled clinical trial. Int J Prev Med. 2016;7:23.

205. Solomon R, Gordon P, Manoukian SV, Abbott JD, Kereiakes DJ, Jeremias A et al. Randomized trial of bicarbonate or saline study for the prevention of contrast-induced nephropathy in patients with CKD. Clin J Am Soc Nephrol. 2015;10(9):1519-24.

206. Sun C, Zhi J, Bai X, Li X, Xia H. Comparison of the efficacy of recombinant human brain natriuretic peptide with saline hydration in preventing contrastinduced nephropathy in patients undergoing coronary angiography with or without concomitant percutaneous coronary intervention. Int J Clin Exp Med. 2015;8(8):14166-72

207. Wang C, Wang W, Ma S, Lu J, Shi H, Ding F. Reduced glutathione for prevention of renal outcomes in patients undergoing selective coronary angiography or intervention. J Interv Cardiol. 2015;28(3):249-56.

208. Xu RH, Ma GZ, Cai ZX, Chen P, Zhu ZD, Wang WL. Combined use of hydration and alprostadil for preventing contrast-induced nephropathy following percutaneous coronary intervention in elderly patients. Exp Ther Med. 2013;6(4):863-7.

209. Zagidullin NS, Dunayeva AR, Plechev W, Gilmanov AZ, Zagidullin SZ, Er F, et al. Nephroprotective effects of remote ischemic preconditioning in coronary angiography. Clin Hemorheol Microcirc. 2017;65(3):299-307.

210. Droppa M, Desch S, Blase P, Eitel I, Fuernau G, Schuler G, et al. Impact of Nacetylcysteine on contrast-induced nephropathy defined by cystatin $\mathrm{C}$ in 
patients with ST-elevation myocardial infarction undergoing primary angioplasty. Clin Res Cardiol. 2011;100(11):1037-43.

211. Huber W, Ilgmann K, Page M, Hennig M, Schweigart U, Jeschke B, et al. Effect of theophylline on contrast material-nephropathy in patients with chronic renal insufficiency: controlled, randomized, double-blinded study. Radiology. 2002;223(3):772-9.

212. Marenzi G, Bartorelli AL. Hemofiltration in the prevention of radiocontrast agent induced nephropathy. Minerva Anestesiol. 2004;70(4):189-91.

213. Masuda M, Yamada T, Okuyama Y, Morita T, Sanada S, Furukawa Y, et al. Sodium bicarbonate improves long-term clinical outcomes compared with sodium chloride in patients with chronic kidney disease undergoing an emergent coronary procedure. Circ J. 2008;72(10):1610-4.

214. Zhang J, Li Y, Tao GZ, Chen YD, Hu TH, Cao XB, et al. Short-term rosuvastatin treatment for the prevention of contrast-induced acute kidney injury in patients receiving moderate or high volumes of contrast media: a sub-analysis of the TRACK-D study. Chin Med J. 2015;128(6):784-9.

215. Sketch MH Jr, Whelton A, Schollmayer E, Koch JA, Bernink PJ, Woltering F, et al. Prevention of contrast media-induced renal dysfunction with prostaglandin E1: a randomized, double-blind, placebo-controlled study. Am J Ther. 2001;8(3):155-62.

216. Acikel S, Muderrisoglu H, Yildirir A, Aydinalp A, Sade E, Bayraktar N, et al. Prevention of contrast-induced impairment of renal function by short-term or long-term statin therapy in patients undergoing elective coronary angiography. Blood Coagul Fibrinolysis. 2010;21(8):750-7.

217. Allie DE, Lirtzman MD, Wyatt CH, Keller VA, Mitran EV, Hebert CJ, et al. Targeted renal therapy and contrast-induced nephropathy during endovascular abdominal aortic aneurysm repair: results of a feasibility pilot trial. J Endovasc Ther. 2007;14(4):520-7.

218. Assadi F. Acetazolamide for prevention of contrast-induced nephropathy: a new use for an old drug. Pediatr Cardiol. 2006;27(2):238-42

219. Avci E, Yesil M, Bayata S, Postaci N, Arikan E, Cirit M. The role of nebivolol in the prevention of contrast-induced nephropathy in patients with renal dysfunction. Anadolu Kardiyol Derg. 2011;11(7):613-7.

220. Awal A, Ahsan SA, Siddique MA, Banerjee S, Hasan MI, Zaman SM, et al. Effect of hydration with or without n-acetylcysteine on contrast induced nephropathy in patients undergoing coronary angiography and percutaneous coronary intervention. Mymensingh Med J. 2011; 20(2):264-9.

221. Azmus AD, Gottschall C, Manica A, Manica J, Duro K, Frey M, et al. Effectiveness of acetylcysteine in prevention of contrast nephropathy. J Invasive Cardiol. 2005;17(2):80-4.

222. Bader BD, Berger ED, Heede MB, Silberbaur I, Duda S, Risler T, et al. What is the best hydration regimen to prevent contrast media-induced nephrotoxicity? Clin Nephrol. 2004;62:1):1-7

223. Barrett BJ, Parfrey PS, Vavasour HM, McDonald J, Kent G, Hefferton D, et al. Contrast nephropathy in patients with impaired renal function: high versus low osmolar media. Kidney Int. 1992:41(5):1274-9.

224. Boccalandro F, Amhad M, Smalling RW, Sdringola S. Oral acetylcysteine does not protect renal function from moderate to high doses of intravenous radiographic contrast. Catheter Cardiovasc Interv. 2003;58(3):336-41.

225. Brar SS, Aharonian V, Mansukhani P, Moore N, Shen AY, Jorgensen M, et al. Haemodynamic-guided fluid administration for the prevention of contrast induced acute kidney injury: the POSEIDON randomised controlled trial. Lancet. 2014;383(9931):1814-23.

226. Briguori C. Renalguard system in high-risk patients for contrast-induced acute kidney injury. Minerva Cardioangiol. 2012;60(3):291-7.

227. Briguori C, Colombo A, Violante A, Balestrieri P, Manganelli F, Paolo Elia $P$, et al. Standard vs double dose of $\mathrm{N}$-acetylcysteine to prevent contrast agent associated nephrotoxicity. Eur Heart J. 2004;25(3):206-11.

228. Briguori C, Visconti G, Focaccio A, Airoldi F, Valgimigli M, Sangiorgi GM, et al. Renal insufficiency after contrast media administration trial II (REMEDIAL II): RenalGuard system in high-risk patients for contrast-induced acute kidney injury. Circulation. 2011;124(11):1260-9.

229. Buyukhatipoglu H, Sezen Y, Yildiz A, Bas M, Kirhan I, Ulas T, et al. Nacetylcysteine fails to prevent renal dysfunction and oxidative stress after noniodine contrast media administration during percutaneous coronary interventions. Pol Arch Med Wewn. 2010;120(10):383-9.

230. Clavijo LC, Pinto TL, Kuchulakanti PK, Torguson R, Chu WW, Satler LF, et al. Effect of a rapid intra-arterial infusion of dextrose $5 \%$ prior to coronary angiography on frequency of contrast-induced nephropathy in high-risk patients. Am J Cardiol. 2006;97(7):981-3.
231. Deray G, Bellin MF, Boulechfar H, Baumelou B, Koskas F, Baumelou A, et al. Nephrotoxicity of contrast media in high-risk patients with renal insufficiency: comparison of low- and high-osmolar contrast agents. Am J Nephrol. 1991;11(4):309-12.

232. Dorval JF, Dixon SR, Zelman RB, Davidson CJ, Rudko R, Resnic FS. Feasibility study of the RenalGuard balanced hydration system: a novel strategy for the prevention of contrast-induced nephropathy in high risk patients. Int J Cardiol. 2013;166(2):482-6.

233. Drager LF, Andrade L, Barros de Toledo JF, Laurindo FR, Machado Cesar LA, Seguro AC. Renal effects of $\mathrm{N}$-acetylcysteine in patients at risk for contrast nephropathy: decrease in oxidant stress-mediated renal tubular injury. Nephrol Dial Transplant. 2004;19(7):1803-7.

234. Erley CM, Duda SH, Schlepckow S, Koehler J, Huppert PE, Strohmaier WL, et al. Adenosine antagonist theophylline prevents the reduction of glomerular filtration rate after contrast media application. Kidney Int. 1994:45(5):142531.

235. Frank H, Werner D, Lorusso V, Klinghammer L, Daniel WG, Kunzendorf U, et al. Simultaneous hemodialysis during coronary angiography fails to prevent radiocontrast-induced nephropathy in chronic renal failure. Clin Nephrol. 2003;60(3):176-82

236. Gandhi MR, Brown P, Romanowski CA, Morcos SK, Campbell S, el Nahas AM, et al. The use of theophylline, an adenosine antagonist in the prevention of contrast media induced nephrotoxicity. Br J Radiol. 1992;65(777):838.

237. Goo JJ, Kim JJ, Kang JH, Kim KN, Byun KS, Kim MK, et al. Effect of reninangiotensin-system blockers on contrast-medium-induced acute kidney injury after coronary angiography. Korean J Intern Med. 2014;29(2):203-9.

238. Han S, Li XM, Mohammed Ali LA, Fu NK, Jin DX, Cong HL. Effect of shortterm different statins loading dose on renal function and $\mathrm{Cl}-\mathrm{AKI}$ incidence in patients undergoing invasive coronary procedures. Int J Cardiol. 2013; 168(5):5101-3.

239. Harris KG, Smith TP, Cragg AH, Lemke JH. Nephrotoxicity from contrast material in renal insufficiency: ionic versus nonionic agents. Radiology. 1991; 179(3):849-52

240. Hoffmann U, Fischereder M, Kruger B, Drobnik W, Kramer BK. The value of $\mathrm{N}$-acetylcysteine in the prevention of radiocontrast agent-induced nephropathy seems questionable. J Am Soc Nephrol. 2004;15(2):407-10.

241. Hoshi T, Sato A, Kakefuda Y, Harunari T, Watabe H, Ojima E, et al. Preventive effect of statin pretreatment on contrast-induced acute kidney injury in patients undergoing coronary angioplasty: propensity score analysis from a multicenter registry. Int J Cardiol. 2014;171(2):243-9.

242. Huber W, Eckel F, Hennig M, Rosenbrock H, Wacker A, Saur D, et al. Prophylaxis of contrast material-induced nephropathy in patients in intensive care: acetylcysteine, theophylline, or both? A randomized study. Radiology. 2006;239(3):793-804.

243. Huber W, Jeschke B, Page M, Weiss W, Salmhofer H, Schweigart U, et al. Reduced incidence of radiocontrast-induced nephropathy in ICU patients under theophylline prophylaxis: a prospective comparison to series of patients at similar risk. Intensive Care Med. 2001;27(7):1200-9.

244. Igarashi $\mathrm{G}$, lino $\mathrm{K}$, Watanabe $\mathrm{H}$, Ito $\mathrm{H}$. Remote ischemic pre-conditioning alleviates contrast-induced acute kidney injury in patients with moderate chronic kidney disease. Circ J. 2013;77(12):3037-44.

245. Katholi RE, Taylor GJ, McCann WP, Woods WT Jr, Womack KA, McCoy CD, et al. Nephrotoxicity from contrast media: attenuation with theophylline. Radiology. 1995;195(1):17-22.

246. Kaya A, Kurt M, Tanboga IH, Isik T, Ekinci M, Aksakal E, et al. Rosuvastatin versus atorvastatin to prevent contrast induced nephropathy in patients undergoing primary percutaneous coronary intervention (ROSA-cIN trial). Acta Cardiol. 2013;68(5):489-94

247. Khanal S, Attallah N, Smith DE, Kline-Rogers E, Share D, O'Donnell MJ, et al. Statin therapy reduces contrast-induced nephropathy: an analysis of contemporary percutaneous interventions. Am J Med. 2005;118(8):843-9.

248. Kini AA, Sharma SK. Managing the high-risk patient: experience with fenoldopam, a selective dopamine receptor agonist, in prevention of radiocontrast nephropathy during percutaneous coronary intervention. Rev Cardiovasc Med. 2001;2(Suppl 1):S19-25.

249. Kolonko A, Wiecek A, Kokot F. The nonselective adenosine antagonist theophylline does prevent renal dysfunction induced by radiographic contrast agents. J Nephrol. 1998;11(3):151-6.

250. Kramer BK, Preuner J, Ebenburger A, Kaiser M, Bergner U, Eilles C, et al. Lack of renoprotective effect of theophylline during aortocoronary bypass surgery. Nephrol Dial Transplant. 2002;17(5):910-5. 
251. Krasuski RA, Beard BM, Geoghagan JD, Thompson CM, Guidera SA. Optimal timing of hydration to erase contrast-associated nephropathy: the OTHER CAN study. J Invasive Cardiol. 2003;15(12):699-702.

252. Kristeller JL, Zavorsky GS, Prior JE, Keating DA, Brady MA, Romaldini TA, et al. Lack of effectiveness of sodium bicarbonate in preventing kidney injury in patients undergoing cardiac surgery: a randomized controlled trial. Pharmacotherapy. 2013;33(7):710-7.

253. Lassnigg A, Donner E, Grubhofer G, Presterl E, Druml W, Hiesmayr M. Lack of renoprotective effects of dopamine and furosemide during cardiac surgery. J Am Soc Nephrol. 2000;11(1):97-104.

254. Lee PT, Chou KI, Liu CP, Mar GY, Chen CL, Hsu CY, et al. Renal protection for coronary angiography in advanced renal failure patients by prophylactic hemodialysis. A randomized controlled trial. J Am Coll Cardiol. 2007:50(11):1015-20.

255. Majumdar SR, Kjellstrand CM, Tymchak WJ, Hervas-Malo M, Taylor DA, Teo KK. Forced euvolemic diuresis with mannitol and furosemide for prevention of contrast-induced nephropathy in patients with CKD undergoing coronary angiography: a randomized controlled trial. Am J Kidney Dis. 2009;54(4):602-9.

256. Marenzi G, Bartorelli AL, Lauri G, Assanelli E, Grazi M, Campodonico J, et al. Continuous veno-venous hemofiltration for the treatment of contrastinduced acute renal failure after percutaneous coronary interventions. Catheter Cardiovasc Interv. 2003;58(1):59-64

257. Miller HI, Dascalu A, Rassin TA, Wollman Y, Chernichowsky T, laina A. Effects of an acute dose of L-arginine during coronary angiography in patients with chronic renal failure: a randomized, parallel, double-blind clinical trial. Am J Nephrol. 2003;23(2):91-5.

258. Mueller C, Buerkle G, Buettner HJ, Petersen J, Perruchoud AP, Eriksson U, et al. Prevention of contrast media-associated nephropathy: randomized comparison of 2 hydration regimens in 1620 patients undergoing coronary angioplasty. Arch Intern Med. 2002;162(3):329-36.

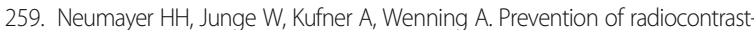
media-induced nephrotoxicity by the calcium channel blocker nitrendipine: a prospective randomised clinical trial. Nephrol Dial Transplant. 1989;4(12):1030-6.

260. Recio-Mayoral A, Chaparro M, Prado B, Cozar R, Mendez I, Banerjee D, et al. The Reno-protective effect of hydration with sodium bicarbonate plus Nacetylcysteine in patients undergoing emergency percutaneous coronary intervention: the RENO Study. J Am Coll Cardiol. 2007:49(12):1283-8.

261. Rosenstock JL, Bruno R, Kim JK, Lubarsky L, Schaller R, Panagopoulos G, et al. The effect of withdrawal of ACE inhibitors or angiotensin receptor blockers prior to coronary angiography on the incidence of contrastinduced nephropathy. Int Urol Nephrol. 2008;40(3):749-55.

262. Schwab SJ, Hlatky MA, Pieper KS, Davidson CJ, Morris KG, Skelton TN, et al. Contrast nephrotoxicity: a randomized controlled trial of a nonionic and an ionic radiographic contrast agent. N Engl J Med. 1989;320(3):149-53.

263. Shavit L, Korenfeld R, Lifschitz M, Butnaru A, Slotki I. Sodium bicarbonate versus sodium chloride and oral $\mathrm{N}$-acetylcysteine for the prevention of contrast-induced nephropathy in advanced chronic kidney disease. J Interv Cardiol. 2009;22(6):556-63.

264. Shemirani H. Pourrmoghaddas M. a randomized trial of saline hydration to prevent contrast-induced nephropathy in patients on regular captopril or furosemide therapy undergoing percutaneous coronary intervention. Saudi J Kidney Dis Transpl. 2012;23(2):280-5

265. Shin DH, Choi DJ, Youn TJ, Yoon CH, Suh JW, Kim Kl, et al. Comparison of contrastinduced nephrotoxicity of iodixanol and iopromide in patients with renal insufficiency undergoing coronary angiography. Am J Cardiol. 2011;108(2):189-94.

266. Sochman J, Krizova B. Prevention of contrast agent-induced renal impairment in patients with chronic renal insufficiency and heart disease by high-dose intravenous N-acetylcysteine: a pilot-ministudy. Kardiol Pol. 2006; 64(6):559-64 discussion 65-6

267. Spangberg-Viklund B, Berglund J, Nikonoff T, Nyberg P, Skau T, Larsson R. Does prophylactic treatment with felodipine, a calcium antagonist, prevent low-osmolar contrast-induced renal dysfunction in hydrated diabetic and nondiabetic patients with normal or moderately reduced renal function? Scand J Urol Nephrol. 1996;30(1):63-8.

268. Staniloae CS, Doucet S, Sharma SK, Katholi RE, Mody KR, Coppola JT, et al. $\mathrm{N}$-acetylcysteine added to volume expansion with sodium bicarbonate does not further prevent contrast-induced nephropathy: results from the cardiac angiography in renally impaired patients study. J Interv Cardiol. 2009;22(3):261-5.

269. Stegmayr BG, Brannstrom M, Bucht S, Crougneau V, Dimeny E, Ekspong A, et al. Low-dose atorvastatin in severe chronic kidney disease patients: a randomized, controlled endpoint study. Scand J Urol Nephrol. 2005;39(6):489-97.
270. Sterner G, Frennby B, Kurkus J, Nyman U. Does post-angiographic hemodialysis reduce the risk of contrast-medium nephropathy? Scand J Urol Nephrol. 2000;34(5):323-6.

271. Stevens MA, McCullough PA, Tobin KJ, Speck JP, Westveer DC, Guido-Allen DA, et al. A prospective randomized trial of prevention measures in patients at high risk for contrast nephropathy: results of the PRINCE Study Prevention of Radiocontrast Induced Nephropathy Clinical Evaluation. J Am Coll Cardiol. 1999;33(2):403-11.

272. Tamai N, Ito S, Nakasuka K, Morimoto K, Miyata K, Inomata M, et al. Sodium bicarbonate for the prevention of contrast-induced nephropathy: the efficacy of high concentration solution. J Invasive Cardiol. 2012;24(9):439-42.

273. Taylor AJ, Hotchkiss D, Morse RW, McCabe JPREPARED. Preparation for angiography in renal dysfunction: a randomized trial of inpatient vs outpatient hydration protocols for cardiac catheterization in mild-tomoderate renal dysfunction. Chest. 1998;114(6):1570-4.

274. Torigoe K, Tamura A, Watanabe T, Kadota J. 20-hour preprocedural hydration is not superior to 5 -hour preprocedural hydration in the prevention of contrast-induced increases in serum creatinine and cystatin C. Int J Cardiol. 2013;167(5):2200-3.

275. Ueda H, Yamada T, Masuda M, Okuyama Y, Morita T, Furukawa Y, et al. Prevention of contrast-induced nephropathy by bolus injection of sodium bicarbonate in patients with chronic kidney disease undergoing emergent coronary procedures. Am J Cardiol. 2011;107(8):1163-7.

276. Weinstein JM, Heyman S, Brezis M. Potential deleterious effect of furosemide in radiocontrast nephropathy. Nephron. 1992;62(4):413-5.

277. Xinwei J, Xianghua F, Jing Z, Xinshun G, Ling X, Weize F, et al. Comparison of usefulness of simvastatin $20 \mathrm{mg}$ versus $80 \mathrm{mg}$ in preventing contrast-induced nephropathy in patients with acute coronary syndrome undergoing percutaneous coronary intervention. Am J Cardiol. 2009;104(4):519-24.

278. Carraro M, Stacul F, Collari P, Toson D, Zucconi F, Torre R, et al. Contrast media nephrotoxicity: urinary protein and enzyme pattern in patients with or without saline infusion during digital subtracting angiography. Contrib Nephrol. 1993;101:251-4.

279. Shakeryan F, Sanati H, Fathi H, Firouzi A, Zahedmehr A, Valizadeh G, et al. Evaluation of combination therapy with vitamin $C$ and pentoxifylline on preventing kidney failure secondary to intravenous contrast material in coronary angioplasty. Iranian Heart J. 2013:17-21.

280. Berger ED, Bader BD, Bosker J, Risler T, Erley CM. Contrast media-induced kidney failure cannot be prevented by hemodialysis. Dtsch Med Wochenschr. 2001;126(7):162-6.

281. Koch JA, Sketch M, Brinker J, Bernink PJ. Prostaglandin E1 for prevention of contrast medium-induced kidney dysfunction. Rofo. 1999;170(6):557-63.

282. Cao S, Wang P, Cui K, Zhang L, Hou Y. Atorvastatin prevents contrast agent-induced renal injury in patients undergoing coronary angiography by inhibiting oxidative stress. Nan Fang Yi Ke Da Xue Xue Bao. 2012;32(11):1600-2.

283. Chen GL, Su JZ. Atorvastatin attenuated contrast induced renal function damage. Zhonghua Xin Xue Guan Bing Za Zhi. 2009;37(5):389-93.

284. Hui H, Li K, Li Z, Wang J, Gao M, Han X. Protective effect of amlodipine against contrast agent-induced renal injury in elderly patients with coronary heart disease. Nan Fang Yi Ke Da Xue Xue Bao. 2012;32(11):1580-3.

285. Wang ZL, Liu M, Zhang YQ. The prevention of denhong injection on contrast-induced renal impairment after percutaneous coronary intervention. Zhongguo Zhong Xi Yi Jie He Za Zhi. 2011;31(12):1611-4.

286. Yin L, Li GP, Liu T, Liu HM, Chen X, He M, et al. Role of probucol in preventing contrast induced acute kidney injury after coronary interventional procedure: a randomized trial. Zhonghua Xin Xue Guan Bing Za Zhi. 2009;37(5):385-8

287. Zhou X, Jin YZ, Wang Q, Min R, Zhang XY. Efficacy of high dose atorvastatin on preventing contrast induced nephropathy in patients underwent coronary angiography. Zhonghua Xin Xue Guan Bing Za Zhi. 2009;37(5):394-6.

288. Diez T, Bagilet D, Ramos M, Jolly H, Diab M, Marcucci R, et al. Evaluation of two methods to avoid the nephropathy associated with radiologic contrast. Medicina (B Aires). 1999;59(1):55-8.

289. El Mahmoud R, Le Feuvre C, Le Quan Sang KH, Helft G, Beygui F, Batisse JP, et al. Absence of nephro-protective effect of acetylcysteine in patients with chronic renal failure investigated by coronary angiography. Arch Mal Coeur Vaiss. 2003;96(12):1157-61.

290. Toprak O, Cirit M, Bayata S, Yesil M, Aslan SL. The effect of pre-procedural captopril on contrast-induced nephropathy in patients who underwent coronary angiography. Anadolu Kardiyol Derg. 2003;3(2):98-103. 
291. Vallero A, Cesano G, Pozzato M, Garbo R, Minelli M, Quarello F, et al. Contrast nephropathy in cardiac procedures: no advantages with prophylactic use of $\mathrm{N}$ acetylcysteine (NAC). G Ital Nefrol. 2002;19(5):529-33.

292. Chen H, Wu H, He Q, Chen H, Mao Y. Comparison of sodium bicarbonate and sodium chloride as strategies for preventing contrast nephropathy [abstract no: SU-PO1046]. J Am Soc Nephrol : JASN. 2007:817A-8A.

293. Grygier M, Janus M, Araszkiewicz A, Kowal J, Mularek-Kubzdela T, OlasinskaWisniewska A, et al. Combined treatment with ascorbic acid and Nacetylcysteine prevents contrast-induced nephropathy in high-risk patients with acute myocardial infarction undergoing percutaneous coronary intervention. Eur heart J. 2011:954-5.

294. Habib M, Hillis A, Hamad A. Low dose of N-acetylcysteine plus ascorbic acid versus hydration with (saline $0.9 \%$ ) for prevention of contrast-induced nephropathy in patients undergoing coronary angiography. Int J Cardiol. 2013:S81-S.

295. Lin M, Sabeti M, Iskandar E, Malhotra N, Pham PT, Pham PC. Prevention of contrast nephropathy with sodium bicarbonate [abstract no: PUB591]. J Am Soc Nephrol : JASN. 2007:959a-60a.

296. Lukas R, Eren A, Keller F, Jehle P. Prevention of contrast nephropathy (cnp) with hydratation and furosemide (fs) [abstract]. Nephrol Dial Transplant. 1999:A73-A.

297. Moreyra A, Natarajan MK, Doucet S, Sharma SK, Staniloae CS, Katholi RE. Contrast nephropathy in patients with chronic kidney disease undergoing either diagnostic or interventional procedures [abstract no:TCT-313]. Am J Cardiol. 2007:124L-L.

298. Ray DS, Srinivas V. Role of n-acetyl cysteine in prevention of contrast nephropathy in patients of diabetic renal failure: a prospective study [abstract]. Nephrol Dial Transplant. 2003:664.

299. Saidin R, Zainudin S, Kong NCT, Maskon O, Saaidin NF, Shah SA. Intravenous sodium bicarbonate versus normal saline infusion as prophylaxis against contrast nephropathy in patients with chronic kidney disease undergoing coronary angiography or angioplasty [abstract no: F-SA-DS911]. Journal of the American Society of Nephrology : JASN. 2006:766A-A.

300. Andrew Lewington RM, Hoefield R, Sutton A, Smith D, Downes M. Prevention of Contrast Induced Acute Kidney Injury (Cl-AKI). In: Adult. Patients. The Renal Association, British Cardiovascular Intervention Society and The Royal College of Radiologists; 2013.

301. Dias S, Welton NJ, Sutton AJ, Caldwell DM, Lu G, Ades AE. Evidence synthesis for decision making 4: inconsistency in networks of evidence based on randomized controlled trials. Med Decis Mak. 2013;33(5):641-56.

302. Zhang JZ, Kang XJ, Gao Y, Zheng YY, Wu TT, Li L, et al. Efficacy of alprostadil for preventing of contrast-induced nephropathy: a meta-analysis. Sci Rep. 2017;7(1):1045

303. Feldkamp T, Baumgart D, Elsner M, Herget-Rosenthal S, Pietruck F, Erbel R, et al. Nephrotoxicity of iso-osmolar versus low-osmolar contrast media is equal in low risk patients. Clin Nephrol. 2006;66(5):322-30.

304. Subramaniam RM, Suarez-Cuervo C, Wilson RF, Turban S, Zhang A, Sherrod C, et al. Effectiveness of prevention strategies for contrast-induced nephropathy: a systematic review and meta-analysis. Ann Intern Med. 2016;164(6):406-16.

Ready to submit your research? Choose BMC and benefit from:

- fast, convenient online submission

- thorough peer review by experienced researchers in your field

- rapid publication on acceptance

- support for research data, including large and complex data types

- gold Open Access which fosters wider collaboration and increased citations

- maximum visibility for your research: over $100 \mathrm{M}$ website views per year

At BMC, research is always in progress.

Learn more biomedcentral.com/submissions 